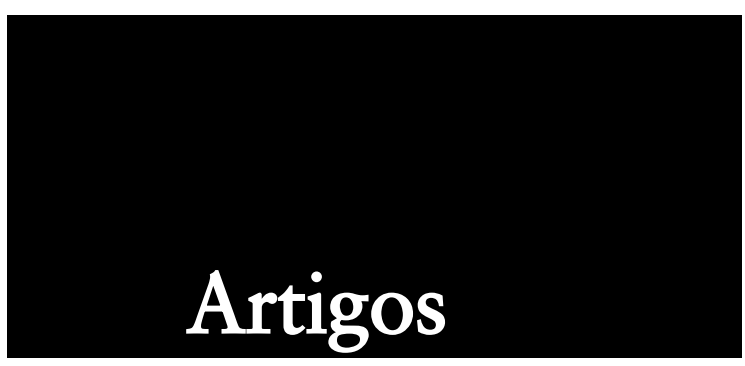

Articles 


\title{
A desigualdade invisível: o papel da classe social na criação dos filhos em famílias negras e brancas ${ }^{1}$
}

\author{
Invisible inequality: the role of social class in raising children \\ from black and white families
}

\begin{abstract}
Annette Lareau ${ }^{2}$

\section{RESUMO}

Apesar de a vida familiar ter um impacto importante nas oportunidades de vida dos filhos, os mecanismos pelos quais os pais transmitem essas vantagens ainda não são totalmente compreendidos. Uma coleta de dados, realizada por meio de ferramentas etnográficas, com crianças brancas e negras de, aproximadamente, 10 anos de idade mostra os efeitos da classe social nas interações dentro de casa. Pais de classe média participam de um cultivo orquestrado (concerted cultivation), ao tentar cultivar os talentos dos filhos através de atividades de lazer organizadas e intensa racionalização. A classe trabalhadora e os pais pobres promovem um crescimento natural (natural growth), oferecendo condições para que os filhos possam crescer, mas deixando as atividades de lazer para as próprias crianças. Estes pais também usam diretivas em vez de racionalização. Os filhos da classe média, tanto brancos como negros, recebem um sentimento emergente de direito através de sua vida familiar. A raça teve muito menos impacto do

\footnotetext{
1 Tradução: Viviane Coelho Caldeira Ramos (mestranda do Programa de Pós-Graduação em Educação da UFMG). Revisão técnica da tradução: Professora Doutora Míriam Jorge (professora da Faculdade de Educação da UFMG).

2 Departamento de Sociologia da Universidade de Maryland, EUA. alareau@socy.umd.edu.
} 
que a classe econômica. Além disso, as diferenças na lógica cultural de criação ofereceram aos pais e aos filhos recursos distintos no momento de interação com profissionais de instituições dominantes e com outros adultos fora do ambiente familiar. Os filhos da classe média ganharam individualmente vantagens insignificantes, mas cumulativamente importantes. As classes trabalhadoras e pobres não apresentaram o mesmo sentimento de direito ou suas vantagens. No entanto, algumas áreas da vida familiar pareceram ser livres dos efeitos de classe social.

Palavras-Chave: classe social, família, criação de filhos, capital cultural, raça.

\begin{abstract}
Although family life has an important impact on children's chances in life, the mechanisms through which parents transmit advantages are imperfectly understood. An ethnographic data set of white and black children around 10 years old shows the effects of social class on interactions at home. Middle-class parents engage in concerted cultivation by attempting to foster children's talents through organized leisure activities and extensive reasoning. Working-class and poor parents engage in the accomplishment of natural growth, providing the conditions under which children can grow, but leaving leisure activities to children themselves. These parents also use commands rather than reasoning. Middle-class children, both white and black, gain an emerging sense of entitlement from their family life. Race had much less impact than social class. Also, differences in a cultural logic of raising children gave parents and their children differential resources to draw on in their interactions with professionals from dominant classes and other adults outside home. Middle-class children gained individually insignificant but cumulatively important advantages. Working-class and poor children did not display the same sense of entitlement or advantages. Some areas of family life appeared immune from the effects of social class, however.
\end{abstract}

Keywords: social class, family, child rearing, cultural capital, race. 


\section{INTRODUÇÃO}

Nas últimas décadas, o conhecimento sociológico acerca das desigualdades na vida familiar cresceu drasticamente. Mesmo assim o debate persiste, especialmente no que diz respeito à transmissão das vantagens de classe para os filhos. Kingston (2000) e outros questionam se aspectos díspares da vida familiar agrupam-se em padrões significativos. Apontando uma "pequena base de evidências" para alegações acerca das diferenças de classe na vida familiar, Kingston também afirma que "a classe não distingue de forma evidente nem os estilos parentais nem o envolvimento das crianças" (p. 134) em comportamentos específicos.

O primeiro problema com diversos estudos é que eles têm foco limitado. Os pesquisadores observam a influência da educação dos pais no envolvimento com a escolarização dos filhos ou a quantidade de tempo que as crianças passam assistindo televisão ou o tempo utilizado para visitar os parentes. Apenas alguns estudos examinam mais de uma dinâmica interna do lar. Em segundo lugar, muito do trabalho empírico é descritivo. Por exemplo, grandes pesquisas têm sido feitas acerca do uso do tempo, incluindo a participação do trabalho feminino no mercado de trabalho, o número de horas que os pais ficam no trabalho e as contribuições das mães e dos pais nos cuidados com as crianças (Herts e Marshall 2001; Jacobs e Gerson 1998: Menaghan 1991). O tempo que os pais passam com os filhos também foi pesquisado (Bianchi 2000; Bianchi e Robinson 1997; Marsiglio 1991; Presser 1989; Zick e Byrant 1996), assim como os padrões de uso do tempo das crianças (Hofferth e Sandberg, 2001b; Juster e Stafford, 1985; Sandberg e Hofferth, 2001). Contudo, esses trabalhos não deram atenção suficiente ao significado dos eventos ou às formas como os diferentes contextos familiares podem afetar certa atividade (ver Daley 2001; Rubin 1976; Thorne 2001). 
Em terceiro lugar, os pesquisadores não explicaram satisfatoriamente como esses padrões observados são produzidos. Isto é, as conceitualizações dos processos sociais, através dos quais as famílias se diferem, não são bem desenvolvidos e pouco se sabe sobre como a vida familiar transmite vantagens às crianças. Poucos pesquisadores tentaram integrar o que se sabe sobre os comportamentos e atitudes ensinados em casa e a forma como essas práticas podem oferecer recursos desiguais para os membros da família fora desse ambiente. Uma exceção importante é o trabalho de Kohn e seus colegas (ex.: Kohn e Schooler 1983), no qual os autores argumentam que pais de classe média valorizam o autodirecionamento, enquanto pais da classe trabalhadora dão mais valor a "conformidade a uma autoridade externa". Esses pesquisadores não investigaram, contudo, como os pais traduzem essas crenças em ações.

Em quarto lugar, pouco se sabe sobre o quanto as crianças adotam e reproduzem as crenças dos pais. Há muito tempo, sociólogos da família têm reforçado a importância de um modelo mais dinâmico de interação pais-filhos (Skolnick,1991), mas uma pesquisa empírica emerge lentamente (ver Hess e Handel, 1974). Os esforços etnográficos em documentar as formas de ações das crianças ofereceram quadros vivenciados, mas muito circunscritos (Shenan 1999; Waksler, 1991). A maioria dos estudos de caso restringe o olhar a apenas uma classe social ou um grupo étnico. Além disso, os etnógrafos, normalmente, não examinam, explicitamente, como as vantagens de classe social são transmitidas aos filhos.

Utilizei-me de descobertas provenientes de um pequeno (mas importante) conjunto de informações coletado por meio de métodos etnográficos. Mapeei as conexões entre os recursos parentais e as vidas diárias dos filhos. Sendo assim, meu primeiro objetivo é desafiar o argumento de Kingston (2000), que afirma que a classe social não causa 
diferenças no comportamento dos pais e na rotina diária dos filhos. Procuro demonstrar empiricamente que a classe social cria estilos parentais distintos. Demonstro que os pais de diferentes classes se diferem na maneira como vêem seus papéis na vida dos filhos, assim como na forma que percebem a infância. Os pais de classe média, tanto brancos como negros, tendem a se ajustar na lógica de criação a qual denomino "cultivo orquestrado". Eles matriculam seus filhos em diversas atividades organizadas, específicas para cada idade, as quais dominam a vida familiar e geram um grande esforço, especialmente para as mães. Os pais vêem essas atividades como uma forma de transmitir às crianças habilidades importantes para a vida. Os pais de classe média também enfatizam o uso da linguagem, o desenvolvimento da razão e utilizam o diálogo como forma de disciplina. Essa abordagem de "cultivo" resulta em um alcance mais amplo de experiências para as crianças, mas também cria um ritmo frenético para os pais, um culto ao individualismo dentro da familia e uma ênfase no desempenho dos filhos. ${ }^{3}$

As estratégias de criação em famílias negras e brancas das classes trabalhadoras e pobres enfatizam o "crescimento natural". ${ }^{4}$ Esses pais acreditam que, desde que ofereçam amor, comida e segurança, seus filhos irão crescer e ser bem-sucedidos. Eles não têm como foco o

\footnotetext{
3 Em um estudo acerca das crenças de mães sobre a criação dos filhos, Hays (1996) descobriu variações sobre como mães de classes trabalhadoras e mães de classe média selecionavam informações, mas que o padrão de "maternidade intensiva" estava presente através das classes sociais. Meu estudo mostrou diferenças de classe, mas, como será discutido posteriormente, em algumas instâncias, os pais de classe trabalhadora e pobre expressaram o desejo de matricular seus filhos em atividades organizadas.

4 Algumas diferenças significativas entre as famílias de classe trabalhadora e pobre participantes do estudo (ex: apenas uma das crianças pobres apresentava carência nutricional) não serão enfatizadas aqui, pois, devido as dimensões discutidas neste artigo, as maiores diferenças eram entre as famílias de classe média e as não pertencentes a esta classe. Ver Lareau (2003) para uma discussão mais elaborada, assim como Lamont (2000) para as distinções feitas por famílias de classe trabalhadora entre elas e as famílias pobres; ver McLanahan e Sandefur (1994) com relação a estrutura familiar e a vida dos filhos.
} 
desenvolvimento de talentos especiais dos filhos. Comparados aos filhos da classe média, os filhos das classes trabalhadoras e pobres participam de poucas atividades organizadas, têm mais tempo livre e ligações mais ricas e profundas com suas famílias estendidas. Pais das classes trabalhadoras e pobres usam mais diretivas e, em algumas casas, colocam mais ênfase na disciplina física do que os pais da classe média. Essas descobertas prolongam as observações de Kohn e Schooler (1983) sobre as diferenças de classe nos valores dos pais, mostrando que as diferenças existem também no comportamento dos pais $e$ dos filhos.

Estudos quantitativos das atividades das crianças oferecem evidência empírica valiosa, mas apenas idéias limitadas sobre como se conceitualizar os mecanismos através dos quais as vantagens sociais são transmitidas. Sendo assim, meu segundo objetivo é oferecer um "guardachuva conceitual", útil para se fazer comparações entre raça e classe, e avaliar o papel da localização da estrutura familiar na forma como a vida diária é moldada. ${ }^{5}$

Finalmente, traço conexões entre a posição de classe dos membros familiares - incluindo os filhos - e os resultados irregulares de suas experiências fora de casa, ao interagirem com profissionais de instituições dominantes. O padrão de cultivo orquestrado encoraja nas crianças um sentimento emergente de direito. Nem todos os pais e filhos têm a mesma assertividade, mas os padrões de questionamento e intervenção das familias de classe média, brancas ou negras, podem ser facilmente contrastados com os apresentados pelas famílias de trabalhadores. $\mathrm{O}$ modelo de crescimento natural encoraja um sentimento

5 Estudos de caso de amostras não aleatórias como este têm como limitação o fato de suas descobertas não poderem ser generalizadas para além dos casos relatados. Estes exemplos servem mais para ilustrar pontos conceituais (Burawoy et al. 1991) do que para descrever padrões de comportamento. Outra limitação deste estudo é que as informações foram coletadas e analisadas durante um longo período de tempo (ver "Metodologia"). 
emergente de restrição. Adultos e crianças dessas classes sociais tendem a ser passivos durante suas interações com profissionais como médicos e educadores. Se comparados à suas contrapartes de classe média, os membros das famílias trabalhadoras e pobres, brancas e negras, tendem a ser mais receosos com esses profissionais. Essas diferenças podem trazer conseqüências em longo prazo. Em um momento histórico, no qual a sociedade dominante privilegia, tanto na área da saúde como na educação, usuários ativos, informados e assertivos, as estratégias empregadas pelos filhos e pais não são igualmente efetivas entre as classes. Em suma, as diferenças na vida familiar não recaem apenas nas vantagens que os pais obtêm para os filhos, mas também nas habilidades transmitidas a eles.

\section{METODOLOGIA}

\section{Participantes do estudo}

Este estudo baseia-se em entrevistas e observações de crianças, com idade entre 8 e 10 anos, e suas famílias. As informações foram coletadas em três fases de pesquisa. A primeira fase envolveu a observação de duas salas de aula de $3^{\text {a }}$ série em uma escola pública na comunidade de Lawrenceville, ${ }^{6}$ localizada no meio-oeste americano. Após conduzir observações por dois meses, agrupei as famílias em categorias de classes sociais (e raça), baseada nas informações dadas pelos educadores. Então, escolhi o terceiro nome de cada lista e enviei uma carta à casa da criança convidando os pais a participarem de entrevistas separadas. Mais de $90 \%$ dos pais concordaram, em um total de 32 crianças (16 brancas e 16 afro-americanas). Eu, juntamente com um aluno negro de pósgraduação, entrevistei todas as mães e a maioria dos pais (ou

\footnotetext{
6 Todos os nomes de lugares e pessoas são pseudônimos. A escola de Lawrenceville era localizada em uma vizinhança branca nos subúrbios de uma comunidade universitária a poucas horas de uma área metropolitana. A população estudantil era metade branca, metade negra; as crianças negras (desproporcionalmente mais pobres) eram trazidas de ônibus de outras vizinhanças.
} 
responsáveis). Cada entrevista durou entre 90 e 120 minutos e se realizaram entre 1989 e 1990.

A segunda fase ocorreu em dois locais situados em uma área metropolitana do noroeste. Uma escola, Lower Richmond, apesar de se localizar em vizinhança urbana predominantemente branca e de classe trabalhadora, tem cerca de metade de seus estudantes provenientes de um projeto de habitação (com moradores exclusivamente negros) localizado próximo à escola. Observei uma classe de $3^{\text {a }}$ série por quase seis meses. $\mathrm{O}$ segundo local, Swan, localizava-se em uma área de subúrbio a 45 minutos do centro da cidade. A escola era $90 \%$ branca, sendo os outros $10 \%$ compostos por crianças negras de classe média. ${ }^{7}$ Neste local fiz observações por dois meses, duas vezes por semana, ao final da $3^{\text {a }}$ série; um pesquisador-assistente os observou na $4^{a}$ série por mais quatro meses. ${ }^{8}$ Em cada local, os pais e professores descreveram a escola de forma positiva. ${ }^{9}$ As observações ocorreram entre setembro de 1992 e janeiro de 1994. No outono de 1993, elaborei uma entrevista-modelo para Lower Richmond e Swan, seguindo o mesmo método de seleção usado em Lawrenceville. Eu e uma equipe de pesquisadores-assistentes entrevistamos os pais e responsáveis de 39 crianças. Novamente, o índice de respostas foi superior a 90\%, no entanto, realizou entrevistas com 17 famílias que tinham crianças de 8 a 10 anos de idade, porque as salas de

\footnotetext{
7 Mais de três quartos dos estudantes de Lower Richmond eram qualificados para o programa de almoço gratuito; em contraste, Swan não oferecia este programa.

8 Em ambos os locais, participamos de eventos escolares e observamos reuniões de pais e professores. Além disso, entrevistei os professores das turmas e demais adultos envolvidos nas atividades organizadas para as crianças. Os dados provenientes dessas entrevistas não são aqui apresentados. ${ }^{9}$ As duas escolas oferecem laboratórios de computação, programas de arte e música, mas a Swan tem mais recursos e atinge notas médias mais elevadas. Pichação e confrontos físicos entre os alunos eram comuns apenas na Lower Richmond. Nesses dois locais e em Lawrenceville, o corpo docente era predominantemente branco.
} 
aula não tinham alunos negros de classe média e alunos brancos pobres em número suficiente para os quadros analíticos. (A maioria dessas entrevistas ocorreu durante os verões de 1996 e 1997. $)^{10}$ Sendo assim, o total de crianças que participaram do estudo foi de 88 (32 do meio-oeste e 56 do noroeste).

\section{Observações das famílias}

A terceira fase, a mais intensiva do estudo, envolveu a observação do lar de 12 famílias, no noroeste dos EUA, que haviam sido previamente entrevistadas (ver Quadro 1). ${ }^{11}$ Alguns temas, tais como o uso da linguagem e os laços sociais da família vieram à tona principalmente nesta fase. Apesar de ter entrado em campo com o interesse de examinar a influência da classe social na vida diária das crianças, incorporei novos temas à medida que esses emergiam nas observações de campo. As evidências aqui apresentada vêm, majoritariamente, da observação das famílias, mas também utilizei, quando apropriado, as descobertas das entrevistas da amostra de 88 crianças. ${ }^{12}$

Nove das doze famílias vieram da amostra das salas do noroeste. As observações dos lares ocorreram entre dezembro de 1993 e agosto de 1994, uma família de cada vez. Três crianças de 10 anos (um menino e

\footnotetext{
10 Localizei os pais de famílias negras de classe média através de contatos sociais; as famílias brancas pobres foram localizadas por meio de folhetos deixados em escritórios voltados para o bemestar social, de programas de serviço social, e colocados em postes de telefones. Apenas dez famílias brancas pobres receberam U\$25 por entrevista.

11 Das 19 famílias convidadas a participar do estudo intensivo, sete declinaram (uma média de resposta de 63\%). Tentei balancear a amostra da fase de observação considerando gênero, raça e classe, assim como "combinar" as crianças e suas características, tais como seu comportamento com os pares, relacionamento com a família estendida e o nível de envolvimento dos pais com sua escolarização. O objetivo disso foi diminuir a possibilidade de que diferenças comportamentais observadas refletissem variáveis desconhecidas (ex: presença na Igreja e participação dos pais na escola). Por último, inclui, deliberadamente, duas famílias (Irwins e Greeleys) que tinham "traços" de classe média, mas que viviam em áreas de classe trabalhadora e pobre, respectivamente. A inclusão dessas famílias atípicas me pareceu importante para separar as influências de classe social e as do ambiente (vizinhança).
} 
uma menina negros de classe média e um menino branco pobre) que não faziam parte da sala de aula da amostra foram observadas em suas casas durante o verão de $1995 .^{13}$

\section{QUADRO 1}

Freqüência de distribuição das crianças do estudo considerando classe social e raça

\begin{tabular}{|c|c|c|c|}
\hline Classe social & Branca & Negra & Total \\
\hline Classe média $^{a}$ & $\begin{array}{c}18 \\
\text { (Garrett Tallinger) } \\
\text { (Melanie Handlon) }\end{array}$ & $\begin{array}{c}18 \\
\text { (Alexander Williams) } \\
\text { (Stacey Marshall) }\end{array}$ & 36 \\
\hline Classe trabalhadorab $^{\mathrm{b}}$ & $\begin{array}{c}14 \\
\text { (Billy Yanelli) } \\
\text { (Wendy Driver) }\end{array}$ & $\begin{array}{c}12 \\
\text { (Tyrec Taylor) }^{(\text {Jessica Irwin) }}{ }^{c}\end{array}$ & 26 \\
\hline Pobre $^{\mathrm{d}}$ & $\begin{array}{c}12 \\
\text { (Kate Greenley) } \\
\text { (Katie Brindle) }\end{array}$ & $\begin{array}{c}14 \\
\text { (Harold McAllister) } \\
\text { (Tara Carroll) }\end{array}$ & 26 \\
\hline Amostra total & 44 & 44 & 88 \\
\hline
\end{tabular}

Nota: Os nomes em cada célula do quadro indicam as crianças selecionadas para participar da fase de observação.

a Crianças de classe média são aquelas que vivem em casas nas quais pelo menos um dos pais está empregado em um posto que exige considerável autoridade gerencial ou necessita de alta escolarização (grau universitário). b Crianças de classe trabalhadora são aquelas que vivem em casas nas quais nenhum dos pais está empregado em um posto de classe média e

\footnotetext{
12 Analisei os dados do estudo de duas formas. Codifiquei os temas das entrevistas e usei o programa de computador Folio Views para estabelecer padrões. Também contei com a leitura das notas de campo, pensando nas similaridades e diferenças entre as famílias, procurando por evidências discordantes e relendo as notas de campo.

$13 \mathrm{O}$ recrutamento para completar a amostra necessária foi difícil, uma vez que as crianças necessitavam ter uma idade, raça, classe e idade específicas, além de estarem dispostos a serem observadas. O menino branco pobre foi recomendado por um gerente de um programa de serviço social; a família negra de classe média foi localizada através da minha rede social.
} 
pelo menos um dos pais está empregado em uma posição com pouca ou nenhuma autoridade gerencial e que não necessita de alto grau de escolarização. Esta categoria inclui funcionários subalternos em empresas e escritórios.

c Uma menina de origem inter-racial (pai negro e mãe branca).

d Crianças pobres são aquelas que vivem em casas nas quais os pais recebem assistência governamental e não tem um trabalho regular.

$\mathrm{Eu}$ e os pesquisadores-assistentes revezamos diariamente nas visitas às famílias participantes, totalizando 20 visitas em cada casa, normalmente em um período de um mês. ${ }^{14}$ As observações foram além da casa: os pesquisadores de campo acompanhavam as crianças e seus pais em atividades escolares, missas/cultos, atividades nas igrejas, jogos, visitas aos familiares e consultas médicas. As observações típicas duravam três horas, mas algumas tiveram maior duração (ex: quando observado um funeral em outra cidade, um evento especial da família estendida ou uma viagem longa para compras). A maioria dos casos também envolveu um pernoite do pesquisador. Normalmente, levamos gravadores de vozes e utilizamos as fitas como referência para escrever as notas de campo. A escrita das notas de campo requereu entre 8 e 12 horas para cada duas ou três horas de visita. Geralmente, cada família participante recebeu U\$350 ao final das visitas.

Trabalhamos em equipes de três. Um pesquisador de campo fazia de três a quatro visitas por semana; outro de uma a duas vezes por semana; e eu visitava uma vez por semana, com exceção daquelas nas quais era a pesquisadora de campo principal. A composição das equipes de pesquisa variou conforme a raça da família. Eu (uma mulher branca de

\footnotetext{
14 Fizemos entre 12 e 14 observações nas famílias Handlon e Carroll antes de decidirmos pelo padrão de 20 visitas. No caso de Alexander Williams, as visitas ocorreram no período de um ano. Para observar eventos fora do comum (ex.: reuniões familiares), voltamos algumas vezes às casas depois que as observações formais haviam acabado.
} 


\section{4}

meia idade) e dois alunos brancos de pós-graduação visitamos as famílias brancas; para as famílias negras as equipes incluíam um aluno de pósgraduação negro, eu e um estudante de pós-graduação branco. Todas as famílias negras com meninos foram visitadas por equipes que incluíam um pesquisador de campo negro. Um pesquisador de campo branco pesquisou a família pobre com um filho branco; os demais pesquisadores de campo brancos eram mulheres. Os membros das equipes se encontraram regularmente para discutir sobre as famílias e revisar os temas analíticos emergentes.

Nossa presença alterou a dinâmica familiar especialmente no início. Com o tempo, no entanto, percebemos sinais de ajustamento (gritos e xingamentos aumentaram a partir do terceiro dia e mais ainda a partir do décimo). As crianças, notadamente, demonstraram gostar de participar do projeto. Elas relataram que isto as fazia se sentirem "especiais". Elas ficavam visivelmente alegres em ver os pesquisadores chegarem e relutantes em deixá-los partir. Os meninos de classe trabalhadora e meninos pobres negros sentiram-se mais confortáveis com os pesquisadores negros do que com as pesquisadoras brancas, principalmente no início. ${ }^{15}$ Contudo, de maneira geral, os membros das famílias relataram nas últimas entrevistas que não mudaram significativamente seu comportamento ou mencionaram alterações bem específicas ("a casa ficou mais limpa").

\footnotetext{
15 As famílias desenvolveram preferências por um pesquisador ou outro de cada equipe. Mas essas diferenças não eram estáveis entre as famílias e as notas de campo dos pesquisadores não foram muito diferentes. As anotações foram muito mais parecidas que divergentes.
} 


\section{UMA OBSERVAÇÃO SOBRE CLASSE}

Participei de observações de campo para desenvolver um quadro realista e intenso da vida familiar. Apesar de ter deliberadamente focado em apenas 12 famílias, queria comparar as crianças em questões de gênero e raça. Não era possível adotar as características bem delimitadas de diferenciação vigentes nos estudos empíricos neo-marxistas e neoweberianos. ${ }^{16}$ Outras limitações foram impostas pela população escolar nos locais selecionados. Poucos alunos eram filhos de empregadores ou de trabalhadores autônomos. Decidi enfocar exclusivamente naquelas cujos pais eram assalariados. A autoridade no local de trabalho e as "barreiras de credencial" foram os critérios mais comuns usados para diferenciação dentro desse grupo heterogêneo. Separei as categorias de famílias trabalhadoras e de classe média baseada em informações detalhadas que cada adulto empregado forneceu acerca do trabalho que realizava, a natureza da organização que o empregava e suas credenciais educacionais. Igualmente, incluí uma categoria tradicionalmente excluída dos agrupamentos de classe: famílias que não estão envolvidas no mercado de trabalho. Na primeira escola estudada, muitas crianças vinham de famílias dependentes da assistência pública. Omiti-las seria restringir arbitrariamente o escopo do estudo. ${ }^{17}$

As três categorias de classe ocultam importantes variações internas. A família Williams (negra) e a família Tallinger (branca) têm rendas muito elevadas, ambas acima de $\mathrm{U} \$ 175.000$; a renda média entre

\footnotetext{
16 Wright (1997) usa 12 categorias em sua abordagem neo-marxista. Goldthorpe, um neo-weberiano, trabalha seu esquema de classe em níveis de agregação que variam de três a 11 categorias. (Erikson e Goldthorpe, 1993: 38-39)

17 Aqui "pobre" refere-se à fonte de renda (assistência governamental versus mercado de trabalho) e não ao valor da renda. Apesar do termo "classe baixa" ser mais preciso do que o termo pobre, ele é amplamente percebido como pejorativo. Poderia haver utilizado o termo underclass, mas a literatura o tem utilizado para lidar com questões de raça.
} 
os pais de família de classe média era bem menor. ${ }^{18}$ A diferença de renda entre as famílias de classe média não estava associada a diferenças de métodos de criação. Além disso, nenhuma outra informação no estudo mostrou fortes diferenças intraclasses. Considero, assim, ser razoável o uso do termo "classe média".

\section{CULTIVO ORQUESTRADO E CRESCIMENTO NATURAL}

As entrevistas e observações sugeriram que aspectos cruciais da vida familiar eram constantes. Dentro das abordagens de cultivo orquestrado e de crescimento natural, três dimensões-chave podem ser distinguidas: a organização da vida diária, o uso da linguagem e os laços sociais (as "intervenções nas instituições" e as "conseqüências" serão trabalhadas posteriormente). Essas dimensões não capturam todas as partes importantes da vida familiar, mas incorporam aspectos centrais da criação dos filhos (Quadro 2). Ademais, nossas observações de campo revelaram que os comportamentos e as atividades relacionadas a estas dimensões dominavam os ritmos da vida familiar.

18 Os valores monetários apresentados são de 1994 e 1995, a não ser que seja dito o contrário. A renda não foi usada como forma de definir a classe, mas a autora dispõe dessa informação. 


\section{QUADRO 2}

Resumo das diferenças entre as abordagens de criação Abordagens de criação

\begin{tabular}{|c|c|c|}
\hline Dimensão observada & Cultivo orquestrado & Crescimento natural \\
\hline $\begin{array}{c}\text { Elementos-chave de cada } \\
\text { abordagem }\end{array}$ & $\begin{array}{c}\text { Os pais encorajam e } \\
\text { va-lorizam o talento, as } \\
\text { opiniões e as habilidades } \\
\text { dos filhos. }\end{array}$ & $\begin{array}{l}\text { Os pais dão os cuidados } \\
\text { básicos e permitem o } \\
\text { crescimento dos filhos. }\end{array}$ \\
\hline Organização da vida diária & $\begin{array}{l}\text { As várias atividades de } \\
\text { lazer dos filhos são } \\
\text { organizadas pelos adultos. }\end{array}$ & $\begin{array}{l}\text { As crianças passam grande } \\
\text { parte do tempo com a } \\
\text { família/parentes. }\end{array}$ \\
\hline Uso da linguagem & $\begin{array}{l}\text { Racionalização/diretivas. } \\
\text { Crianças contestam os } \\
\text { adultos. Negociações ex- } \\
\text { tensas entre pais e filhos. }\end{array}$ & $\begin{array}{c}\text { Diretivas. Crianças rara- } \\
\text { mente questionam/ } \\
\text { desafiam os adultos. } \\
\text { Crianças aceitam as diretivas. }\end{array}$ \\
\hline Laços sociais & $\begin{array}{l}\text { Laços fracos com a família } \\
\text { estendida. Crianças estão } \\
\text { normalmente em grupos } \\
\text { de idade homogênea. }\end{array}$ & $\begin{array}{l}\text { Laços fortes com a família } \\
\text { estendida. Crianças estão } \\
\text { normalmente em grupos } \\
\text { de idade heterogênea. }\end{array}$ \\
\hline $\begin{array}{l}\text { Intervenção nas } \\
\text { instituições }\end{array}$ & $\begin{array}{c}\text { Crítica e intervenção a } \\
\text { favor da criação. Criança é } \\
\text { ensinada a intervir em seu } \\
\text { próprio interesse. }\end{array}$ & $\begin{array}{l}\text { Dependência das insti- } \\
\text { tuições. Sentimento de } \\
\text { inutilidade e frustração. } \\
\text { Conflito entre as práticas } \\
\text { de criação da casa e as } \\
\text { práticas escolares. }\end{array}$ \\
\hline Conseqüências & $\begin{array}{l}\text { Sentimento emergente de } \\
\text { direito por parte da criança. }\end{array}$ & $\begin{array}{l}\text { Sentimento emergente de } \\
\text { restrição por parte da criança. }\end{array}$ \\
\hline
\end{tabular}

Conceitualmente, a organização da vida cotidiana e o uso da linguagem são dimensões cruciais. Elas devem estar presentes para que uma família possa ser descrita como engajada em um tipo de criação. Os laços sociais são significantes, mas menos essenciais do ponto de vista conceitual.

Todos os três aspectos da criação dos filhos estavam intrinsecamente ligados à rotina familiar, mas eram raramente percebidos. Como parte de uma prática diária, esses aspectos eram invisíveis para os pais e para os filhos. Contudo, analiticamente, esses mecanismos são úteis para se comparar e contrastar as maneiras como as diferenças de classe social desenham a vida familiar. Agora, examinarei duas famílias nessas três dimensões. Fiz um 
"controle" de etnia e gênero e contrastei as vidas de dois meninos negros um de classe média alta e outro de uma família que conta com ajuda governamental. Poderia haver focado em, praticamente, qualquer uma das 12 crianças, mas esse par me pareceu o mais adequado, considerando o número limitado de trabalhos acerca de famílias negras de classe média e meu argumento que sugere que a raça é menos importante do que a classe no desenvolvimento de modelos de criação dos filhos.

\section{CULTIVANDO ALEXANDER WILLIAMS}

Alexander Williams e seus pais vivem em uma vizinhança predominantemente habitada pela classe média negra. Sua casa, com seis quartos, custa em torno de U\$150.000. ${ }^{19}$ Alexander é filho único. Os pais cresceram em pequenas cidades no sul dos Estados Unidos e vêem de famílias grandes. O pai, um homem alto e bonito, é um advogado de tribunal bem-sucedido e que ganha, aproximadamente, U\$125.000 por ano em uma pequena firma especializada em casos de erro médico. Duas semanas por mês ele trabalha por períodos prolongados (de $5 \mathrm{~h} 30$ da manhã até meia-noite) preparando os julgamentos. Nas outras duas semanas seu horário de trabalho vai até as 18 horas. Ele raramente viaja para fora da cidade. A mãe de Alexander, Christina, é uma mulher sardenta, positiva e vivaz, com um longo cabelo negro cacheado. ${ }^{20}$ Diretora de alto escalão em uma grande corporação, ela tem um escritório luxuoso, secretária pessoal e responsabilidade sobre outros escritórios no

\footnotetext{
19 Os pais não concordaram com o preço da casa: o valor aqui dado é a média entre os valores relatados por ambos em 1995. O valor imobiliário naquela região era mais baixo - e continua até hoje mais baixo - do que em outros locais do país. A propriedade vale hoje aproximadamente entre U\$175.000 e U\$200.000.

20 A mãe de Alexander é chamada de Christina Nile no trabalho, mas na Igreja atende por senhora Williams. O último nome de algumas mães também difere de seus filhos. Neste trabalho dei às mães o mesmo sobrenome de seus filhos.
} 
país. Ela tenta limitar suas viagens, mas ao menos uma vez por mês tem de fazer viagens que incluem pernoite.

Alexander é um menino charmoso, curioso e com um sorriso encantador. A mãe se mostra satisfeita pelo filho parecer interessado em tantas coisas: "Alexander é uma alegria. Ele é um presente. Ele é uma pessoa cheia de energia, muito curioso, amável e cuidadoso, que, uh... É extrovertido e que, uh, realmente gosta de estar com as pessoas. Ele adora explorar, ama ler e, simplesmente, fazer várias coisas divertidas."

A escola particular na qual Alexander estuda ${ }^{21}$ tem um programa de atividades extraclasse. Alexander participa de várias dessas atividades e tem aulas de violão e fotografia.

\section{ORGANIZAÇÃO DA VIDA DIÁRIA}

Alexander é muito ocupado com suas atividades durante e final de semana (Quadro 3). Sua mãe descreve a rotina de sábado de manhã. O dia começa cedo com aulas particulares de piano no centro da cidade, localizado a 20 minutos de sua casa:

A aula começa às 8h15. Para mim, foi uma troca. Eu tenho uma opinião muito forte sobre o que passa na TV sábado de manhã. Eu não sei em que ela contribui. Então... era... uh... ou ficar em casa e brigar no sábado de manhã [risos] ou fazer algo construtivo... Agora os sábados de manhã já estão reservados. Sabe, as aulas de piano e depois direto para o ensaio do coral que dura umas duas horas. Então, o horário dele é bem cheio.

A oposição veemente da senhora Williams à televisão é baseada no que acredita ser necessário para que Alexander cresça e tenha sucesso.

\footnotetext{
21 Contatei a família Williams através da minha rede de contatos, após não ter conseguido recrutar a família negra de classe média que havia participado das fases de observação e de entrevista. Como resultado, não tenho informações relativas às observações de sala de aula ou às reuniões de pais e professores.
} 
Ela se opõe à passividade da TV e sente ser sua obrigação ajudar o filho a cultivar seus talentos.

Algumas vezes Alexander reclama: "minha mãe me inscreve em tudo!”. Não obstante, ele, normalmente, gosta das suas atividades. Ele diz que elas o fazem se sentir "especial" e sem elas sua vida seria um "tédio". Seu sentido de tempo é muito ligado a suas atividades. Ele se sente desorientado quando seu horário não está ocupado. Este mal estar fica claro neste fragmento retirado de uma anotação de campo. A família voltava para a casa depois de um evento na escola que reunia os pais, alunos e professores. Alexander estava mal-humorado porque não tinha nada planejado para o outro dia. Ele queria que um amigo fosse para sua casa, mas a mãe recusou. Choramingando, ele se pergunta o que irá fazer. A mãe, resumidamente, diz: "Você tem piano e violão. Você vai ter algum tempo livre [pausa]. Acho que você sobrevive por uma noite. [Alexander não responde, mas parece bravo. Todos ficam quietos pelo resto do caminho.]"

Os pais de Alexander acreditam que suas atividades oferecem uma ampla gama de importantes benefícios para seu desenvolvimento. Ao falar sobre as aulas de piano de Alexander, o senhor Williams aponta que como um aluno Suzuki, ${ }^{22}$ Alexander já consegue ler partituras. Especulando sobre os benefícios mais difusos do envolvimento de Alexander com o piano, ele diz:

\begin{abstract}
vejo como a adolescência e a vida adulta de uma pessoa não possam ser melhores por saber quem foi Beethoven. Isso é Bach ou Mozart? Eu não sei a diferença entre os dois! Eu não sei diferenciar o Barroco do Clássico, mas ele sabe. Como isso não pode ser benéfico no futuro? Estou convencido que esta experiência tão rica o irá transformar em uma pessoa melhor, um cidadão melhor, um marido melhor, um pai melhor e, certamente, um aluno melhor.
\end{abstract}

22 O método Suzuki é baseado no trabalho intenso. É exigido que os alunos escutem música por cerca de uma hora diariamente. Além disso, tanto as crianças como o(s) pai(s) deve(m) praticar diariamente e participar juntos de todas as aulas. 
QUADRO 3

Participação em atividades fora da escola: meninos

\begin{tabular}{|c|c|c|}
\hline Nome/Raça/Classe & $\begin{array}{c}\text { Atividades organizadas } \\
\text { por adultos }\end{array}$ & Atividades informais \\
\hline \multicolumn{3}{|l|}{ Classe média } \\
\hline Garrett Tallinger (branco) & $\begin{array}{c}\text { Time de futebol } \\
\text { Viagem com o time de } \\
\text { futebol } \\
\text { Time de beisebol } \\
\text { Time de basquete } \\
\text { (durante verão) } \\
\text { Time de natação } \\
\text { Saxofone (ligado à escola) }\end{array}$ & $\begin{array}{c}\text { Brinca com os irmãos } \\
\text { no quintal } \\
\text { Assiste televisão } \\
\text { Joga no computador } \\
\text { Passa a noite na casa de } \\
\text { amigos }\end{array}$ \\
\hline Alexander Williams (negro) & $\begin{array}{c}\text { Time de futebol } \\
\text { Time de beisebol } \\
\text { Coral comunitário } \\
\text { Coral da Igreja } \\
\text { Catequese } \\
\text { Piano (Suzuki) } \\
\text { Peças de teatro da escola } \\
\text { Violão (ligado à escola) }\end{array}$ & $\begin{array}{l}\text { Televisão restrita } \\
\text { Ocasionalmente brinca } \\
\text { fora de casa com outros } \\
\text { dois meninos } \\
\text { Visita amigos da escola }\end{array}$ \\
\hline \multicolumn{3}{|l|}{ Classe trabalhadora } \\
\hline Billy Yanelli (branco) & Time de beisebol & $\begin{array}{c}\text { Assiste televisão } \\
\text { Visita parentes } \\
\text { Anda de bicicleta } \\
\text { Brinca na rua } \\
\text { Passa o tempo com as } \\
\text { crianças da vizinhança }\end{array}$ \\
\hline Tyrec Taylor (negro) & $\begin{array}{c}\text { Time de futebol } \\
\text { Escola bíblica (férias) } \\
\text { Catequese (não regular) }\end{array}$ & $\begin{array}{c}\text { Assiste televisão } \\
\text { Brinca na rua } \\
\text { Anda de bicicleta com } \\
\text { os vizinhos } \\
\text { Visita parentes } \\
\text { Vai à piscina }\end{array}$ \\
\hline \multicolumn{3}{|l|}{ Pobre } \\
\hline Karl Greely (branco) & $\begin{array}{l}\text { Vai à piscina } \\
\text { Juntamente com um vizinho, } \\
\text { anda com os cachorros }\end{array}$ & $\begin{array}{c}\text { Assiste televisão } \\
\text { Joga Nintendo } \\
\text { Brinca com os irmãos }\end{array}$ \\
\hline Harold McAllister (negro) & $\begin{array}{l}\text { Estudo bíblico na casa de } \\
\text { vizinho (ocasionalmente) } \\
\text { Acampamento bíblico } \\
\text { (duração de uma semana) }\end{array}$ & $\begin{array}{c}\text { Visita parentes } \\
\text { Joga bola com os vizinhos } \\
\text { Assiste televisão } \\
\text { Assiste vídeos }\end{array}$ \\
\hline
\end{tabular}


A senhora Williams vê a música como forma de construir a "confiança" e a "postura" do filho. Nas entrevistas e em conversas casuais, ela enfatiza a "exposição". Ela acredita ser sua responsabilidade alargar a visão de mundo de Alexander. As atividades na infância proporcionam o terreno para a aprendizagem de habilidades importantes para a vida:

Os esportes oferecem grandes oportunidades para aprender a ser competitivo. Aprender a aceitar a derrota, sabe. Aprender como aceitar a vitória, sabe, de uma forma graciosa.Também dá a oportunidade de aprender habilidades de liderança e saber como ser um jogador de equipe... Os esportes realmente oferecem várias ótimas oportunidades.

Os horários de Alexander estão sempre mudando; algumas atividades acabam e outras se iniciam. Como os calendários de práticas esportivas e jogos são liberados apenas depois do início da temporada, é raramente possível fazer um planejamento com antecedência. Devido ao grande número de atividades de Alexander, as atividades e eventos inevitavelmente se sobrepõem. Algumas atividades, apesar de durarem pouco, consomem muito tempo. A peça de teatro da escola, por exemplo, requer ensaios por três noites durante a última semana antes da estréia. Além disso, ao escolher as atividades, a família Williams leva em conta outra preocupação: o equilíbrio racial do grupo. A senhora Williams prefere que Alexander não seja a única criança negra no evento. Normalmente, um ou dois meninos negros estão envolvidos, mas os grupos são predominantemente brancos e as atividades ocorrem em vizinhanças majoritariamente brancas. Todavia, Alexander participa do coral jovem da Igreja e da catequese, atividades nas quais todos os participantes são negros.

Muitas atividades envolvem competição. Alex precisa, por exemplo, fazer um teste para sua performance solo na peça de teatro da escola. Da mesma forma, tanto os pais como as crianças entendem que a 
participação nas equipes esportivas " $A$ " ou "B" ou no time de "estrelas" indica diferentes níveis de habilidade. Assim como outras crianças de classe média deste estudo, Alexander parece gostar de se apresentar em público. De acordo com uma nota de campo, após apresentar seu solo em uma produção musical na frente de 200 pessoas, ele parecia "contido, satisfeito, consciente da atenção que estava recebendo".

Os compromissos de Alexander não consomem todo seu tempo livre, mesmo assim sua vida é definida por prazos finais e programações entremeadas por uma série de atividades organizadas e controladas pelos adultos e não pelas crianças. Nem ele nem seus pais vêem isso como problemático.

\section{USO DA LINGUAGEM}

Bem como outras famílias de classe média, os Williams freqüentemente participam de conversas que promovem a racionalização e a negociação. Um trecho retirado de anotações de campo (descrevendo o diálogo entre Alexander e sua mãe dentro do carro depois do acampamento de verão) mostra o tipo de pergunta aguçada que os pais de classe média fazem a seus filhos. A senhora Williams não está apenas obtendo informações. Ela também está dando a Alexander a oportunidade de desenvolver e praticar suas habilidades verbais, como resumir, clarear e ampliar a informação:

[Enquanto dirige, a senhora Williams pergunta a Alex]: "Então como foi seu dia?"

Alex: Ok! Eu comi cachorro-quente hoje, eles estavam queimados! Estavam todos pretos!

Mãe: Ah, que ótimo! Você não deveria ter comido nenhum.

Alex: Eles não estavam todos pretos, só a metade deles. O resto estava normal.

Mãe: Ah, tá. Qual o jogo vocês estava jogando hoje de manhã? 
Alex: Ele chamava "Que que você tá fazendo?"

Mãe: E como é que joga?

[Alexander explica o jogo de maneira elaborada...

O pesquisador não acompanha muito bem. A mãe faz algumas perguntas durante a explicação, dizendo: “ ah, sei”, quando pergunta. Ela o questiona sobre outro jogo que ela o viu jogando; ele explica... Ela continua a estimulá-lo e encorajá-lo com risadinhas enquanto ele explica.] Expressões de interesse nas atividades dos filhos, freqüentemente, levam a negociações sobre pequenos assuntos familiares. Durante o mesmo trajeto, a senhora Williams tenta adaptar o cardápio do jantar de acordo com Alexander:

Alex: Eu não quero cachorro-quente hoje à noite. Mãe: É? Porque você comeu no almoço.

[Alexander concorda com a cabeça.]

Mãe: Bom, então vou arrumar alguma coisa e amanhã à noite comemos cachorro-quente.

Alex: Mas eu também não quero picadinho de porco.

Mãe: Bom, Alexander, nós temos que comer alguma coisa. Por que você não comeu um hambúrguer hoje?

Alex: Eles não tem mais hambúrguer na cantina. [A mãe pergunta se Alexander está bem e se ele quer um lanche. Alexander diz que está bem. A mãe pergunta se ele tem certeza que não quer um saco de batatinhas.]

Nem todos os pais de classe média são tão preocupados com as necessidades de seus filhos como esta mãe e nenhum está sempre interessado em negociar. No entanto, é comum um padrão de racionalização e acomodação.

\section{LAÇOS SOCIAIS}

O casal Williams se considera muito ligado a suas famílias estendidas, porque os pais deles moram no sul do país, visitá-los requer viagens aéreas. Duas vezes por ano, a senhora Williams leva Alexander 
para visitar os avós. Ela fala com os pais por telefone pelo menos uma vez por semana e também conversa com os irmãos várias vezes durante a semana. O senhor Williams conversa com a mãe regulamente por telefone (ele tem menos contato com o padrasto). Ele menciona, com orgulho, a sobrinha cuja educação, em uma universidade de renome, ele está ajudando a financiar.

As interações com os primos normalmente não constituem parte do tempo de lazer de Alexander. (Como explicarei posteriormente, outras crianças de classe média também não viam seus primos, mesmo quando estes moravam próximos.) Assim como ele também não brinca com as crianças do bairro. As enormes casas na rua dos Williams são ocupadas majoritariamente por casais sem filhos. A maioria dos amigos de Alexander é de sua sala ou das atividades organizadas. Visto que a maioria dos eventos escolares, a vida na Igreja e as outras diversas atividades são organizadas pela idade (e às vezes pelo sexo) dos participantes, Alexander interage quase que exclusivamente com crianças da sua própria idade, normalmente meninos. Dessa maneira, as atividades organizadas pelos adultos definem o contexto de sua vida social.

O casal Williams está consciente que eles alocam uma parcela considerável do tempo nas atividades de Alexander. O que enfatizam, no entanto, são as vezes que não o fazem. Eles mencionam atividades que a família escolheu não participar (tais como as viagens de futebol).

\section{RESUMO}

De maneira geral, os pais de Alexander participam de um cultivo orquestrado. Eles encorajam o crescimento do filho através do envolvimento com a música, com a Igreja e com as atividades esportivas e acadêmicas. Eles conversavam longamente com o filho sobre suas opiniões e encorajavam suas idéias. Sua abordagem envolvia consideráveis despesas diretas (custo das aulas e equipamentos) e indiretas (custo de 
tirar tempo fora do trabalho, transporte para as práticas e abrir mão das atividades de lazer adultas). Apesar do casal Williams reconhecer a importância da família estendida, Alexander passa, relativamente, pouco tempo com seus parentes. Suas interações sociais ocorrem quase que exclusivamente com crianças da sua própria idade e com adultos. As várias atividades de Alexander formatam significativamente a organização da vida diária da família. O tempo de lazer dos pais foi planejado para acomodar os compromissos do filho. O casal Williams acredita que as estratégias cultivadas por eles para o filho resultarão em melhor chance de Alexander obter uma vida feliz e produtiva. Eles não conseguem se imaginar não investindo grande parte do seu tempo e energia na vida do filho. Entretanto, como explicarei na próxima seção, que focaliza um garoto negro de família pobre, outros pais têm uma visão diferente.

\section{APOIANDO O CRESCIMENTO NATURAL DE HAROLD MCALLISTER}

Harold McAllister, um garoto forte, robusto e com um grande sorriso, vem de uma família negra pobre. Ele mora com a mãe e uma irmã de oito anos, Alexis, em um amplo apartamento, onde dois primos costumam passar a noite. A irmã de 16 anos e o irmão de 18 moram com a avó, mas, às vezes, ficam na casa dos McAllister. A senhora McAllister, formada no ensino médio, depende do auxílio público. Hank, o pai de Harold e Alexis, é mecânico. Ele e a senhora McAllister nunca foram casados. Ele visita a família regularmente (algumas vezes semanalmente) depois do trabalho para ver televisão ou cochilar. Harold (mas não Alexis), às vezes, atravessa a cidade de ônibus para passar o fim de semana com Hank.

O apartamento dos McAllister localiza-se em um conjunto habitacional público, perto de uma rua movimentada. O complexo consiste em fileiras de prédios de dois e três andares. Os edifícios, 
marrons e atarracados, têm pequenos gramados rodeados de cercas de concreto e madeira. Grandes refletores são colocados nos cantos dos prédios, e largos passeios de concreto cortam os espaços entre as unidades. O gramado está falho em alguns locais; embrulhos de papel e pedaços de vidro sujam a área.

Dentro do apartamento, a vida é divertida e espirituosa, com os membros da família dividindo a rotina diária. A senhora McAllister falava, com desdém, sobre mães que usam drogas, ou abusam do álcool e não "cuidavam" dos filhos. De fato, no ano anterior a senhora McAllister chamou o Serviço de Proteção à Criança para denunciar sua irmã gêmea, uma viciada em cocaína, pois esta estava negligenciando os filhos. A senhora McAllister é ativamente envolvida na vida dos sobrinhos, filhas de sua irmã gêmea. Os dois sobrinhos também ficam com ela freqüentemente. De maneira geral, ela se vê como uma mãe capaz que cuida dos filhos e de sua família estendida.

\section{ORGANIZAÇÃO DA VIDA DIÁRIA}

Grande parte da vida de Harold e dos outros membros da família gira entorno da família. Os moradores do conjunto freqüentemente se reuniam no gramado ou na frente dos prédios, bebendo cerveja, conversando e observando as crianças brincarem. Durante o verão, as janelas ficam normalmente abertas, deixando a brisa circular entre as unidades e fornecendo pontos de observação através dos quais os residentes podem inspecionar a vizinhança. Uma grande árvore caducifólia em frente ao apartamento dos McAllister oferece uma sombra muito bem-vinda no calor do verão.

Harold ama esportes. Ele é particularmente apaixonado por basquete, mas também gosta de futebol americano e acompanha com afinco os esportes profissionais televisionados. Na maior parte das tardes, ele ou está em dentro de casa assistindo televisão ou fora de casa jogando 
bola. Ele participa de jogos de futebol americano com os primos e vizinhos e organiza jogos de basquete. Algumas vezes, ele e os amigos usam uma cesta enferrujada, sem rede, presa em um poste de telefone ou amarram uma outra para servir de cesta. Um obstáculo para a prática de esportes, no entanto, é a falta de equipamentos. As bolas são caras para serem repostas, especialmente devido à velocidade que elas desaparecem - o roubo de equipamento das crianças, como bolas e bicicletas, é um problema constante. Durante uma observação de campo, Harold perguntou a mãe se ela sabia onde estava a bola. Ela respondeu com alguma veemência: "Eles roubaram a bola azul e a amarela, eles roubaram a bola verde e eles roubaram a outra bola."

A caça às bolas é parte da rotina no tempo de lazer de Harold. Em um dia de junho, com alta umidade e temperatura acima de $27^{\circ} \mathrm{C}$, Harold, seu primo Tyrice e um pesquisador de campo perambularam por cerca de uma hora tentando achar uma bola de basquete:

[Estávamos indo para o outro lado do complexo. No caminho, passamos por quatro garotos sentados nas escadas. As idades variavam de 9 a 14 anos. Eles tinham um rádio ligado. Dois deles tentavam ardorosamente trocar um pneu furado de uma bicicleta. Os outros dois quicavam uma bola de basquete.]

Harold: E aí, beleza, galera?

Grupo: Que que tá pegando, Har? Beleza? E aî? [Eles continuaram a trocar o pneu e a quicar a bola. Enquanto caminhávamos morro abaixo, Harold perguntou: "Oh, posso usar sua bola?" O rapaz respondeu, tirando os olhos do pneu, "Nem, cara, 'cê pode perder".]

Harold, Tyrice e o pesquisador andaram para outra parte do conjunto habitacional, em direção a uma quadra de basquete improvisada onde eles esperavam encontrar algum jogo já acontecendo: "Não tivemos 
sorte." Harold entra em um apartamento em frente à quadra improvisada. A porta está aberta... Harold volta: "Sem bola. Acho que é melhor voltar".

O ritmo da vida de Harold e seus amigos segue a maré dos interesses das crianças e das obrigações familiares. No dia da procura pela bola de basquete, por exemplo, após passar o tempo ouvindo música e olhando figurinhas de basquete, as crianças entram em uma "guerra de água" instigada por Tyrice. É uma brincadeira cheia de energia, recheada de gargalhadas e esforços para molhar os adultos próximos (contra a vontade deles). Quando a brincadeira acaba, as crianças pedem dinheiro às mães, o recebe e então vão a uma loja para comprar refrigerante e salgadinhos. Eles conversam com outro garoto e depois caminham devagar para casa, enquanto comem. Em outra tarde, quase duas semanas depois, as crianças - Harold, dois de seus primos e dois vizinhos - e o pesquisador jogam basquete em uma quadra improvisada na rua (usando a bola do pesquisador). Assim que Harold começa a quicar a bola, as crianças da vizinhança se aproximam.

Dessa maneira, a vida de Harold flui muito mais livre e muito mais direcionada pelas crianças do que a de Alexander William. O ritmo de cada dia não é planejado e sim emergente, refletindo os interesses e as atividades da criança. Os pais intervêem em áreas específicas, tais como a aparência pessoal, refeições, e eventuais tarefas de casa, mas não direcionam e monitoram continuamente as atividades de lazer das crianças. Além disso, as atividades de lazer que Harold e outras crianças de classe trabalhadora e pobre participam requerem que desenvolvam um repertório de habilidades que os permitam lidar com crianças muito mais velhas e muito mais novas, assim como com os vizinhos e parentes. 


\section{USO DA LINGUAGEM}

A vida nas famílias de classe trabalhadora e pobre presentes no estudo corre bem, sem grandes discussões verbais. A quantidade de conversas varia, mas, em geral, é bem menos freqüente do que nas casas de classe média. ${ }^{23}$ A senhora McAllister faz piadas com as crianças e discute o que passa na televisão, mas não parece cultivar uma conversa, perguntando ou incentivando-as. Por exemplo, ela coordena o uso do único banheiro do apartamento, usando diretivas de apenas uma palavra. Ela manda as crianças (há quase sempre quatro crianças em casa) se lavarem apontando para uma delas e dizendo a palavra "banheiro" e entregando a ela uma toalha. Sem dizer nada, a criança designada levantase e vai ao banheiro tomar banho.

Da mesma forma, apesar de a senhora McAllister ouvir as reclamações das crianças sobre a escola, ela não instiga essas questões ou tenta descobrir detalhes, como faria a senhora Williams. Por exemplo, no começo do novo ano letivo, quando perguntei a Harold sobre a sua professora, ele me disse que ela era "má" e "mentirosa". A senhora McAllister, enquanto enxugava a louça, ouvia o filho e não o encorajou a basear sua opinião sobre a professora com exemplos e nem mencionou suas próprias preocupações. Ao invés disso, ela perguntou sobre o professor do ano passado: "Qual era o nome daquele professor?”, Harold responde, "Senhor Lindsey". Ela diz: "Não, o outro". Ele diz "Senhor Terrene". A senhora McAllister sorri e diz: "É, eu gostava dele". Ao contrário da mãe de Alexander, ela parece satisfeita com esta breve troca de informação.

\footnotetext{
23 Hart e Risley (1995) relataram diferença similar nos padrões de fala. Em sua amostra, por volta dos três anos, os filhos de pais empregados tinham maior vocabulário e falavam mais frases por hora do que os pais de crianças com idade similar que viviam com ajuda governamental.
} 


\section{LAÇOS SOCIAIS}

As crianças, em especial os garotos, freqüentemente brincam fora de casa. $\mathrm{O}$ número de amigos potenciais no mundo de Harold é muito maior do que na vizinhança de Alexander. Quando uma pesquisadora parou para contar, descobriu 40 crianças no ensino fundamental residindo nos blocos de apartamentos próximos. Com tantas crianças, Harold poderia escolher brincar apenas com aquelas de mesma idade. Entretanto, na realidade, ele passa o tempo com crianças mais velhas e mais novas e com os primos (que tem idade próxima).

A família McAllister, assim como outras famílias pobres e trabalhadoras, está envolvida em uma rede de parentesco estendida. Como dito anteriormente, os irmãos mais velhos de Harold assim como os dois primos costumam passar a noite na casa dos McAllister. Celebrações, como aniversários, envolvem, quase exclusivamente, os membros da família. Os convidados das festas não são, como ocorre nas famílias de classe média, os amigos da escola e das atividades extracurriculares. Os aniversários são comemorados entusiasticamente com bolo e comidas especiais para marcar a ocasião; presentes, no entanto, não são oferecidos. No Natal a casa de Harold tinha uma árvore e também comida especial, mas nenhum presente. Nestes e em outros eventos familiares as crianças mais velhas, voluntariamente, cuidam das mais novas: Harold brinca com a sobrinha de 16 meses e seus primos carregam os bebês mais novos.

A importância dos laços familiares - e a natureza contingente da vida no mundo dos McAllister - fica clara na resposta que Alexis oferece ao ser perguntada o que faria se ganhasse um milhão de dólares:

Nossa! Eu compraria pro meu irmão, pra minha irmã, pro meu tio, pra minha tia, pras minhas sobrinhas, pros meus sobrinhos e pro meu avô, e pra minha avó, e pra minha mãe, e pro meu pai, e pros meus amigos, não pros meus amigos, mas mais pra minha melhor amiga, eu 


\section{2}

compraria pra eles todos roupas... e tênis. E eu compraria alguma comida, e compraria pra minha mãe alguma comida e eu daria presentes de aniversário pros meus irmãos e pras minhas irmãs.

\section{RESUMO}

Em um contexto no qual todos, inclusive as crianças, estão extremamente conscientes da falta de dinheiro, a família McAllister faz as coisas acontecerem. A senhora McAllister, acertadamente, se vê como uma mãe muito capaz. Ela foi uma influência forte e positiva nas vidas das crianças que cuida. Mesmo assim, o contraste com a senhora Williams é marcante. A senhora McAllister não parecia pensar que as opiniões de Harold precisavam ser cultivadas e desenvolvidas. Ela, como a maioria dos pais de classe trabalhadora e de famílias pobres, marcava limites fortes e claros entre os adultos e as crianças. Os adultos davam direções às crianças. As crianças tinham a liberdade de brincar informalmente, a não ser que tivessem que realizar algum serviço doméstico. As relações com a família estendida eram consideravelmente importantes e confiáveis.

\section{A INTERSEÇÃO DE RAÇA E CLASSE NA VIDA FAMILIAR}

Eu esperava que a raça tivesse grande influência na conformação das atividades diárias, mas isso não foi evidenciado (ver também Conley 1999; Pattillo-McCoy, 1999). Isto não significa que a raça não é importante. Os pais negros estavam particularmente preocupados em monitorar a vida dos filhos fora de casa, à procura de sinais de problemas raciais. ${ }^{24}$ Especialmente os pais de famílias negras de classe média

\footnotetext{
24 Esta seção foca primariamente nas preocupações de pais negros. Os brancos, claro, também se beneficiaram pelas relações de raças, notadamente na dispersão de famílias brancas pobres vizinhas de classe trabalhadora, ao invés de estarem concentradas em ambientes densamente populosos por outras famílias pobres (Massey e Denton 1993).
} 
enfatizaram a importância de fazer os filhos entenderem o que “significava ser um homem negro nesta sociedade" (J.Hochschild, 1995). O senhor Williams, ao resumir como ele e a mulher orientavam Alexander, disse:

[Nós tentamos] ensiná-lo que a raça é infelizmente o aspecto mais importante da nossa vida neste país. Eu quero dizer, as pessoas olham para as outras pessoas e o que vêem em primeiro lugar é a cor. Só que isto não definirá o que ele é. Ele fará o melhor que puder. Ele vai ter sucesso apesar do racismo. E eu acho que ele vive a vida dessa maneira.

Os pais de Alexander estavam bem conscientes do potencial significado da raça na vida do filho. Ambos, no entanto, foram firmes ao afirmar que a raça deve ser usada como "desculpa" para não tentar ser bemsucedido. Assim se coloca o senhor Williams: "Eu converso sobre como a raça tem impacto na minha vida como advogado, eu discuto como a raça irá impactar a vida dele. Um ensinamento que ele leva com isso é que ele nunca deve usar a discriminação como uma desculpa para não fazer o melhor que pode." Até hoje poucos incidentes envolvendo racismo ocorreram na vida de Alexander, sua mãe relata: "As situações foram há algum tempo e poucas... quer dizer, eu posso contar nos dedos."

Mesmo assim a senhora Williams recontou, com uma dor clara, um incidente ocorrido em uma festa de aniversário a qual Alexander foi quando estava no maternal. Os avós do aniversariante perguntaram repetidas vezes: "Quem é esse menino?", e completavam: "Ele é tão escuro!”. Tais experiências levaram os Williams a adotar uma postura "precavida": "Nós nunca fomos, uh, o tipo de pais que deixam os filhos em qualquer lugar. Nós sempre vamos com ele. Até hoje eu entro - na escola pela manhã - e observo... Nós prestamos muita atenção no ambiente escolar." 


\section{4}

Os pais de Alexander não são igualmente otimistas sobre as chances de igualdade racial no país. A senhora Williams acredita fortemente que, enquanto Alexander for novo, o pai não deve demonstrar pessimismo. $\mathrm{O}$ senhor Williams reclamou que isso significava que ele tinha que prestar atenção no que ele dizia para Alexander sobre as relações raciais. Mesmo assim os pais concordavam sobre a necessidade de serem vigilantes frente a possíveis problemas raciais na vida de Alexander. Outros pais negros relataram experiências de preconceito racial e demonstraram um comprometimento similar com a vigilância.

Questões relativas à perspectiva de tornar-se um adulto negro nesta sociedade também permearam a vida de Alexander sem equivalência entre seus pares de classe média branca. Espera-se que, ao crescer, Alexander passe a presenciar experiêncais raciais, o que ainda não ocorre na $4^{a}$ série. Com relação ao número e tipo de atividades das quais ele participa, elas eram bem semelhantes às de Garry Tallinger, sua contraparte branca (ver Quadro 3). Podemos perceber que os pais de ambos os garotos estavam fortemente comprometidos com a estratégia de cultivo orquestrado, visto o número de atividades organizadas pelos adultos nas quais os garotos estavam inscritos, o ritmo acelerado da família e a ênfase na racionalização das negociações entre pais e filhos. Da mesma forma, eu e os pesquisadores-assistentes não percebemos nenhuma grande diferença na forma como os pais brancos e negros de famílias trabalhadoras e pobres socializavam seus filhos.

Outros (Fordham e Ogbu 1986) descobriram que no fim do ensino fundamental e no ensino médio os grupos de pares adolescentes costumam criar barreiras raciais, esse padrão não ficou evidente entre os participantes do estudo de $3^{\mathrm{a}}$ e $4^{\mathrm{a}}$ séries (mas, por vezes, apresentado pelos irmãos mais velhos). Ecoando Tatum (1997, p. 52), atribuo este fenômeno à pouca idade das crianças (ver também "Race in America", The New York Times, 25 de junho, 2000, p. 1).Em suma, na sociedade como 
um todo, aspectos primordiais da vida diária foram desenhados pela segmentação racial e pela discriminação. No entanto, em termos de participação em atividades organizadas, uso da linguagem e laços sociais, as maiores diferenças entre as famílias foram observadas entre as classes sociais e não entre grupos raciais.

\section{DIFERENÇAS DE PRÁTICAS}

\section{CULTURAIS NA AMOSTRA TOTAL}

Os padrões observados entre as famílias Williams e McAllister ocorreram em meio a uma sub-amostra de 12 famílias e estas de um grupo ainda maior de 88 crianças. Freqüentemente, elas ecoaram padrões já estabelecidos na literatura. Esses padrões enfatizam não apenas a quantidade de tempo das atividades, mas também a qualidade de vida familiar e as formas de ligação entre as dimensões-chave da criação dos filhos.

\section{ORGANIZAÇÃO DA VIDA DIÁRIA}

Neste estudo, de forma geral, os ritmos de vida das famílias variaram entre as classes sociais. As crianças da classe trabalhadora e pobre passavam grande parte de seu tempo livre em brincadeiras informais; as crianças de classe média participavam de atividades organizadas por adultos, criadas para desenvolver seus talentos e interesses individuais. Baseada nas respostas dadas pelos pais durantes as entrevistas, ${ }^{25}$ calculei a média de atividades organizadas ${ }^{26}$ para as 88 crianças. As crianças de classe média tinham uma média de 4,9 atividades

\footnotetext{
25 Atividades consideradas como organizadas: escoteiros/bandeirantes, aulas de música, qualquer tipo de aulas esportivas (ginástica, caratê), qualquer tipo de evento esportivo organizado (campeonatos juvenis), aulas de dança, coral, aulas de orientação religiosa (excluindo as aulas em colégios religiosos), aulas de arte e artesanato e qualquer atividade realizada em centros de recreação.

26 Assim como descoberto em outros trabalhos, as mães tinham muito mais conhecimento sobre a rotina dos filhos do que os pais e também passavam mais tempo cuidando deles (Crouter et. Al. 1999; Thompson 1999). A observação nas famílias mostrou que o pai tem um papel muito importante na dinâmica familiar, especialmente trazendo o humor (Lareau 2000b).
} 
naquele momento $(\mathrm{N}=36)$; famílias de classe trabalhadora 2,5 atividades $(\mathrm{N}=26)$ e as crianças pobres tinham em média 1,5 $(\mathrm{N}=26) .{ }^{27}$ As crianças de famílias negras de classe média tinham um pouco mais de atividades do que as crianças brancas de mesma classe social, essas atividades estavam mais ligadas ao envolvimento destas com a Igreja, uma média de $5,2(\mathrm{~N}=18)$ em comparação com 4,6 entre os brancos $(\mathrm{N}=18)$. A diferença racial foi pequena no grupo de famílias trabalhadoras, 2.8 atividades para as crianças negras $(\mathrm{N}=12)$ contra 2,3 atividades para as brancas $(\mathrm{N}=14)$ e entre o grupo de famílias pobres. Meninos de classe média têm um pouco mais de atividades do que meninas da mesma classe (5,1 versus $4.7, \mathrm{~N}=18$ para ambos), mas o sexo não fez diferença nas outras classes sociais. As meninas tendem a participar de dança, música, grupos de bandeirantes/escoteiras e são menos ativas nos esportes. Esse padrão de diferenças entre classes sociais pode ser comparado com trabalhos mais antigos (Medrich et al. 1982). Recente pesquisa realizada por Hofferth e Sandberg (2001a, 2000b) utilizando uma amostra nacional representativa, sugere que o número de atividades organizadas das quais as crianças fazem parte aumenta conforme a educação dos pais e que o envolvimento das crianças nesse tipo de atividade cresceu nos últimos anos.

O custo dessas atividades organizadas é significativo, principalmente quando as famílias têm mais de um filho. Os gastos

\footnotetext{
27 Estão faltando alguns dados. A lista de atividades era tão extensa que, por vezes, tivemos que reduzi-la por limitações de tempo (no entanto, sempre perguntamos aos entrevistados se havia alguma atividade que os filhos já haviam feito e que não constava na lista). Em geral, os pais de classe média não foram perguntados sobre 2,5 itens entre as 20 possibilidades da lista; os trabalhadores, 3,0; e os pobres, 2,0. Uma vez que esta amostra não é aleatória, os procedimentos de inferência não se aplicam. Por pedido de um resenhador, realizei um teste Scheffe post hoc de diferenças de grupo e encontrei profundas diferenças (nível de $\mathrm{p}<.001$ ) entre as crianças de classe média e pobre. A diferença entre as crianças de família trabalhadora e pobre não foi significante (nível de $\mathrm{p}<.05$ ). Não ocorreram diferenças estatisticamente significantes entre grupos raciais e gênero; nem há interações significativas entre raça ou gênero e classe.
} 
incluem pagamento de instrutores e técnicos, compra de uniforme e equipamentos, taxas de torneios, viagens para participação em campeonatos, incluindo transporte, alimentação e pernoites. Os acampamentos de verão também são caros. Atendendo a meu pedido, a família Talliger somou os custos das atividades de Garrett. O total foi superior a U $\$ 4.000$ por ano. Relatórios recentes sobre os gastos dos pais com um esporte (ex.: hóquei) são comparativamente altos (Schemari, 2002). As atividades das crianças também consomem tempo, interferindo no tempo limitado de lazer dos pais. 


\section{QUADRO 4}

Participação em atividades fora da escola: meninas

\begin{tabular}{|c|c|c|}
\hline Nome/Raça/Classe & $\begin{array}{l}\text { Atividades organizadas } \\
\text { por adultos }\end{array}$ & Atividades informais \\
\hline \multicolumn{3}{|l|}{ Classe média } \\
\hline Melanie Handlon (branca) & $\begin{array}{c}\text { Bandeirantismo } \\
\text { Piano } \\
\text { Catequese } \\
\text { Igreja } \\
\text { Concurso da Igreja } \\
\text { Violino (ligado à escola) } \\
\text { Time de softball }\end{array}$ & $\begin{array}{c}\text { Televisão restrita } \\
\text { Brinca fora de casa com os } \\
\text { vizinhos } \\
\text { Faz biscoitos com a mãe } \\
\text { Nada (não faz parte do } \\
\text { time) } \\
\text { Ouve música }\end{array}$ \\
\hline Stacey Marshall (negra) & $\begin{array}{c}\text { Aulas de ginástica } \\
\text { Time de ginástica } \\
\text { Igreja } \\
\text { Catequese } \\
\text { Coral juvenil }\end{array}$ & $\begin{array}{c}\text { Assiste televisão } \\
\text { Brinca fora de casa } \\
\text { Visita amigos da escola } \\
\text { Anda de bicicleta }\end{array}$ \\
\hline \multicolumn{3}{|l|}{ Classe trabalhadora } \\
\hline Wendy Driver (branca) & $\begin{array}{c}\text { Aula de educação católica } \\
\text { Aula de dança } \\
\text { Coral da escola }\end{array}$ & $\begin{array}{c}\text { Assiste televisão } \\
\text { Visita parentes } \\
\text { Faz os deveres de casa } \\
\text { Anda de bicicleta } \\
\text { Brinca na rua } \\
\text { Passa o tempo com os primos }\end{array}$ \\
\hline $\begin{array}{c}\text { Jessica Irwin } \\
\text { (pai negro e mãe branca) }\end{array}$ & $\begin{array}{c}\text { Igreja } \\
\text { Catequese } \\
\text { Aula de artes ao sábado } \\
\text { Banda da escola }\end{array}$ & $\begin{array}{c}\text { Televisão restrita } \\
\text { Leitura } \\
\text { Brinca fora de casa com os } \\
\text { vizinhos } \\
\text { Visita parentes }\end{array}$ \\
\hline \multicolumn{3}{|l|}{ Pobre } \\
\hline Katie Brindle (branca) & $\begin{array}{c}\text { Coral da escola } \\
\text { Grupo da Igreja sexta à } \\
\text { noite (raramente) } \\
\text { Igreja } \\
\text { Catequese }\end{array}$ & $\begin{array}{c}\text { Assiste televisão } \\
\text { Visita parentes } \\
\text { Brinca de Barbie } \\
\text { Anda de bicicleta } \\
\text { Brinca com os vizinhos }\end{array}$ \\
\hline Tara Carroll (negra) & & $\begin{array}{c}\text { Assiste televisão } \\
\text { Visita parentes } \\
\text { Brinca com bonecas } \\
\text { Joga Nintendo } \\
\text { Brinca com os vizinhos }\end{array}$ \\
\hline
\end{tabular}


O estudo também revelou diferenças quanto à quantidade de tempo que as crianças passam em atividades controladas por adultos. Consideremos os horários de Melanie Handlon, uma garota de classe média que cursa a $4^{a}$ série (ver Quadro 4). Entre os dias 8 e 24 de dezembro, Melanie teve aulas de piano todas as segundas-feiras, grupo de bandeirantes todas as quintas, um evento especial das bandeirantes em uma segunda à noite, apresentação de musical natalino na escola em uma terça à noite, duas consultas dentárias, cinco ensaios para o concurso natalino da Igreja, além de seus compromissos regulares de domingo (serviço religioso, catequese e coral). Nos dias de semana, ela passava várias horas após a escola lutando com o dever de casa enquanto a mãe a acompanhava passa-a-passo. A quantidade de tempo que Melanie gastava em atividades controladas por adultos foi parecida com as de outras crianças de classe média do estudo.

Os horários de Katie Brindle, uma aluna de $4^{a}$ série de uma família pobre, são bem diferentes, com poucas atividades organizadas entre os dias 2 e 24 de dezembro. Ela cantou no coral da escola, em ensaios de uma hora às quartas feiras, e retornou sozinha para casa após os ensaios. Ocasionalmente, Katie participou de um encontro de jovens cristãos em uma sexta à noite (3 de dezembro). Significativamente, todas as outras atividades foram livres. Ela queria se matricular em aulas de balé, mas elas eram muito caras. O tempo de lazer de Katie não era estruturado. Normalmente, ela voltava para a casa após as aulas e brincava com outras crianças da vizinhança ou assistia televisão. Freqüentemente, ela também visitava a avó e os primos que moravam a poucos minutos de carro ou ônibus. De maneira geral, a vida de Katie girava em torno da casa dela. Comparada com a vida das crianças de classe média deste estudo, sua vida tinha um ritmo bem menos agitado. Essa característica foi comum entre as famílias trabalhadoras e pobres que entrevistamos. 
Além dessas atividades, a televisão se mostrou a principal fonte de entretenimento. Todas as crianças do estudo passavam pelo menos parte do tempo assistindo TV, mas havia diferenças relativas a " quando", "o que" e "quanto tempo" se dedicavam a essa atividade. A maioria dos pais de classe média entrevistados caracterizava a televisão como altamente ou potencialmente prejudicial aos filhos, muitos enfatizaram que preferiam que os filhos lessem. Esses pais geralmente tinham regras sobre a quantidade de tempo que as crianças poderiam assistir televisão. ${ }^{28}$ Essas preocupações não apareceram nas entrevistas com pais trabalhadores e pobres. Na realidade a senhora Yanelli, uma mãe branca trabalhadora, era contra a restrição de acesso a televisão considerando que: "Você aprende muito com a televisão, sabe?". Os pais de classe trabalhadora e pobre monitoravam o conteúdo dos programas e "censuravam" alguns deles, no entanto, a televisão, em si, era deixada quase que continuamente ligada (ver também Robinson e Godbey, 1997).

\section{USO DA LINGUAGEM}

As diferenças de classe social no uso da língua são parecidas com as apresentadas por outros (ver Bernstein, 1971; Hart e Risley, 1995: Heath, 1983). Em casas de classe média, os pais colocavam muita ênfase na racionalização. Eles também consideravam as opiniões dos filhos em assuntos específicos. Esses pais utilizavam diretivas ao lidar com assuntos de saúde e segurança, mas a maioria dos outros aspectos da vida cotidiana estava aberta a negociações: o que a criança vestia, comia, onde se sentava e como passava seu tempo livre. Contudo, nem todas as famílias de classe

\footnotetext{
${ }^{28}$ Dados recentes sugerem que a quantidade de tempo que os pais de classe média dizem que seus filhos assistem de televisão é muito menor do que o tempo real de exposição (Hofferth, 1999). Essa diferença não é tão grande nos dados apresentadas pelos pais com menor índice educacional.
} 
média eram igualmente abertas ao diálogo. Além disso, durante as observações, as mães mostravam mais disposição em debater com os filhos do que os pais. Estes últimos tendiam, de maneira geral, a se engajarem menos com as crianças e a aceitarem menos alguma interrupção (A Hochschild, 1989).

Em famílias trabalhadoras e pobres a maioria dos pais não enfatizava o desenvolvimento das opiniões, julgamentos e observações das crianças. Quando os filhos voluntariamente davam alguma informação, os pais ouviam, mas, normalmente, não faziam perguntas ou comentários. No trecho abaixo, retirado de notas de campo, Wendy Driver apresenta para os demais membros da sua família branca de classe trabalhadora sua nova visão de pecado. Ela está sentada na sala de estar com o irmão (Willie), com a mãe e o parceiro da mãe (Mack). Todos estão assistindo televisão:

\footnotetext{
Wendy pergunta a Willie: Você sabe o que é pecado mortal? Willie: Não!

Wendy pergunta a mãe: Você sabe o que pecado mortal?

Mãe: O que é?

Wendy pergunta a Mack: Você sabe o que é? Mack: Não!

Mãe: Conta para gente o que é. Você é que foi para a aula de educação religiosa.

Wendy: É quando você sabe que alguma coisa está errada, mas faz assim mesmo.

Ninguém presta atenção ao comentário de Wendy. Sua mãe e Mack olharam para ela enquanto dava a explicação e depois voltaram a assistir a televisão.]
}

A família de Wendy é cooperativa quanto à conversa, mas, ao contrário da família Williams, por exemplo, ninguém percebe o momento como uma oportunidade para desenvolver o vocabulário de Wendy ou ajudá-la a desenvolver suas habilidades de pensamento crítico. 
As negociações entre pais e filhos nas famílias de classe trabalhadora e pobre não eram freqüentes. Os pais tendiam a usar diretivas firmes e esperavam respostas afirmativas e rápidas. As crianças que ignoravam a instrução parental podiam esperar uma punição física. Anotações de campo feitas durante uma noite na família trabalhadora branca Yanelli captura um exemplo dessa dinâmica familiar. Já passava das 20 horas e a senhora Yanelli, seu filho Billy e o pesquisador estavam jogando Scrabble. ${ }^{29}$ O senhor Yanlli e um amigo estão absortos em uma partida de xadrez. Durante a noite, Billy e a senhora Yanelli estão às turras. Ela quer que o filho pare de jogar, tome banho e vá para a cama.

\footnotetext{
Mãe: Billy, banho. Não me importo se você chorar, gritar.

Billy: Ainda não terminamos o jogo de Scrabble. Mãe: Você terminou. Terminasse seu dever de casa mais cedo. [Nesse dia, Billy só terminou os deveres às 20 horas. Billy permanece sentado.] Mãe: Vamos! Amanhã você tem um dia cheio. [Billy não se mexe.]

[A mãe vai para um outro cômodo e pega um cinto de couro marrom. Ela bate duas vezes na perna de Billy.]

Mãe: Suba agora mesmo! Amanhã eu não vou conseguir te acordar. Levanta agora mesmo! [Billy se levanta e sobe as escadas correndo.]
}

A abordagem disciplinar da senhora Yanelli é bem diferente da dos pais de classe média observados. Assim como grande parte dos pais de classe trabalhadora e pobre estudados, ela usa diretivas e suas instruções não são negociáveis ("Billy, banho" e "Você terminou"). O uso do cinto pode parecer duro, mas não foi uma forma de punição aleatória

29 Scrabble é um jogo de tabuleiro, cujo objetivo é formar palavras a partir de letras distribuídas. (N. do T.) 
ou irracional. A senhora Yanelli apresentou suas expectativas e ofereceu uma explicação (está tarde e amanhã ele terá um “dia cheio”). Ela buscou a disciplina física como um recurso quando percebeu que Billy não estava respondendo. ${ }^{30}$

\section{LAÇOS SOCIAIS}

Observamos também as diferenças de classe no contexto das relações sociais das crianças. Entre as 88 crianças, o envolvimento das de classe média em atividades desenvolvidas por adultos criava laços sociais mais fracos. O futebol, as aulas de fotografia, o time de natação e assim por diante ocorrem em blocos com duração de 6 a 8 semanas e a rotatividade dos membros é relativamente alta. Igualmente importante, é o fato das atividades organizadas geralmente reduzirem o contato com a família estendida. Alguns não tinham parentes vivendo próximos, mas entre aqueles que tinham, os horários das crianças tornava difícil a organização e participação em encontros regulares com a família estendida. Muitas das crianças de classe média visitavam os parentes apenas nos feriados principais. ${ }^{31}$

Igualmente, os pais de classe média tendiam a manter laços sociais mais frágeis. A maioria relatou ter uma rede de relacionamento que incluía profissionais das áreas de saúde e ensino: $93 \%$ da amostra de pais de classe média tinha um amigo ou parente que era professor, contra 43\% dos trabalhadores e $36 \%$ dos pobres. Quanto a amigos e familiares

\footnotetext{
30 Durante a entrevista, a senhora Yanelli calculou que, durante as duas semanas prévias, havia usado duas vezes o cinto. Ela afirmou que o seu uso variava muito. Nem todos os pais trabalhadores e pobres deste estudo utilizavam o castigo físico, mas a grande maioria contava fortemente com as diretivas.

31 As entrevistas tinham respostas abertas: as respostas variadas dos entrevistados impediram o resumo dos dados em uma escala única que medisse eficientemente as diferenças entre classes dos laços familiares.
} 


\section{4}

médicos, o padrão foi similar ( $70 \%$ versus $14 \%$ e $18 \%$, respectivamente). ${ }^{32}$ Relacionamentos como esses não são tão profundos como os laços familiares, mas são um bom recurso quando os pais enfrentam algum desafio na criação dos filhos.

Famílias trabalhadoras e pobres tinham menos probabilidade de incluir esses profissionais em sua rede de relacionamentos, mas tinham mais probabilidade de ver ou falar diariamente com membros da família do que seus contrapartes de classe média. As crianças interagiam regularmente de forma casual em grupos com idades heterogêneas que incluíam primos e vizinhos. Como mostrado por outros (Lever, 1988), observamos diferenças de gênero nas atividades. Apesar das meninas, algumas vezes, aventurarem-se a andar de bicicleta ou a jogar bola fora de casa, elas brincavam mais dentro de casa. Tanto dentro como fora de casa, meninos e meninas brincavam em grupos soltos, junto com familiares e vizinhos, criando suas próprias atividades.

As interações com representantes de instituições sociais (polícia, justiça, escolas e agências governamentais) também pareceram ser significativamente moldadas pela classe social. Membros de famílias trabalhadoras e pobres, brancas e negras, comentaram espontaneamente sobre sua descrença frente a essas instituições. Por exemplo, uma mãe branca trabalhadora descreveu um episódio no qual um policial foi até sua casa procurar seu ex-marido (usuário de drogas). Ela lembra dos policiais "colocando a porta a baixo" e amedrontando seu filho mais velho, que tinha então três anos de idade. Outra mãe branca trabalhadora relatou que seu pai fora preso. Apesar de todos acreditarem que ele estava bem, ele foi

32 A amostra geral incluiu 36 famílias de classe média, 26 trabalhadoras e 26 pobres. Para a pergunta sobre os professores, houve respostas de 31 pais de classe média, 21 de trabalhadores e 25 de pobres. Para a pergunta sobre os médicos, as repostas de cada classe foram de 26,21 e 22 . Da mesma forma, encontramos resultados relativos a psicólogos, terapeutas familiares e advogados (informação disponível com a autora). A raça não influenciou nos resultados. 
encontrado morto na prisão da cidade, devido a um alegado suicídio. As crianças ouviam e pareciam absorver esses tipos de observações.

O medo era a razão fundamental para o desconforto apresentado pelas famílias trabalhadoras e pobres em situações de encontros formais (e informais) com autoridades. Alguns pais se preocupavam que estes iriam "vir e tirar [seus] filhos". Uma mãe negra, que contava com assistência pública, entrevistada no estudo mais amplo, se mostrou escandalizada quando o pessoal da escola deixou sua filha voltar para a casa sem casaco em um dia de inverno. Ela disse que se ela deixasse isso acontecer, "a escola" iria denunciá-la ao Serviço de Proteção à Criança por abuso infantil. A mãe de Wendy Driver (branca, trabalhadora) reclamou que se sentia obrigada a levar Wendy ao médico, mesmo sabendo que não havia nada de errado, porque Wendy tinha ido à enfermaria da escola. A senhora Driver sentia que tinha que ser extremamente cuidadosa porque não queria que "eles" viessem e levassem seus filhos embora. ${ }^{33}$ Por outro lado, nenhum pai de classe média mencionou medos similares frente às instituições dominantes.

Obviamente as três dimensões do padrão de criação dos filhos organização da vida diária, uso da linguagem e laços sociais - não capturam todas as vantagens de classe que os pais passam para seus filhos. Os filhos de classe média do estudo tinham vidas relativamente privilegiadas. Viviam em casas grandes, algumas com piscinas no quintal, a maioria tinha seu próprio quarto, todos tinham muitos brinquedos, e computadores eram comuns. Essas crianças também tinham horizontes abertos, andavam de avião, iam para outros estados durantes as férias,

\footnotetext{
33 É difícil avaliar o quão errônea é a suspeita dos pais. A conselheira escolar de Lower Richmond, que normalmente relatava as crianças como vítimas de negligência ao departamento de Serviços Humanos, afirmou que ela só reportava os casos mais graves e só depois de várias intervenções. No entanto, os pais trabalhadores e pobres, geralmente, viam as "ações da escola" como imediatas, inconstantes e arbitrárias.
} 
freqüentemente viajavam cerca de uma ou duas horas para participar de suas atividades e conheciam, em suas atividades extracurriculares, crianças mais velhas que já haviam viajado para o exterior.

Mesmo assim, em áreas importantes, as variações entre as famílias não pareciam estar ligadas à classe social. Algumas das crianças de classe média tinham problemas de aprendizagem. E, apesar de sua posição social relativamente privilegiada, as crianças e pais de classe média não estavam isolados da realidade de doenças graves e mortes prematuras entre amigos e familiares. Além disso, alguns elementos da vida familiar pareciam relativamente imunes à classe social, incluindo o quão arrumada era a casa. A casa de uma família branca de classe média estava em constante caos. A casa foi limpa e arrumada para as festividades de Natal, mas retornou a seu estado normal pouco tempo depois. Ao contrário, a casa de uma família negra de classe média estava sempre extremamente arrumada, assim como algumas, mas não todas, as casas de famílias trabalhadoras e pobres. Outros aspectos da criação dos filhos, como o grau que as mães pareciam "estar falando sério", não estavam ligados à classe social. As famílias também se diferenciaram em relação à presença ou ausência de senso de humor entre seus membros, níveis de ansiedade e sinais de estresse. Finalmente, havia diferenças significativas no temperamento e disposições entre crianças da mesma família. Essas variações são importantes para nos lembrar que a classe social não é completamente determinante no caráter da vida das crianças.

\section{IMPACTO DAS ESTRATÉGIAS DE CRIAÇÃO DOS FILHOS NA INTERAÇÃO COM INSTITUIÇÕES}

Por vezes, os cientistas sociais enfatizam a importância de reconfigurar as práticas parentais para melhorar as chances de sucesso dos filhos. Explícita e implicitamente, a literatura estimula os pais a 
obedecerem à visão dos profissionais (Bronfenbrenner, 1996; Epstein, 2001; Heimer e Staffen, 1998). Esses convites à cumplicidade, no entanto, não levam em consideração o julgamento dos profissionais com relação aos valores intrínsecos dos modelos de criação atuais e as evidências históricas, que mostram mudanças regulares desses padrões durante o tempo (Aries, 1962; Wringly, 1989: Zelizer, 1985). Também não analisam as possibilidades estratificadas e limitadas de sucesso na sociedade mais ampla.

Agora, sigo as famílias para fora de suas casas em encontros com representantes de instituições dominantes - instituições essas que são dirigidas por profissionais de classe média. Novamente, focarei Alexander Williams e Harold McAllister (experiências com instituições estão resumidas no Quadro 2). Através de todas as classes sociais, pais e filhos interagiram com professores, pessoal da escola, profissionais da área de saúde e oficiais governamentais. Apesar de relacionadas com problemas parecidos (ex.: problemas de aprendizagem, asma, violações de trânsito), as soluções não eram parecidas. O padrão de cultivo orquestrado gerava um sentimento emergente de direito na vida de Alexander Williams e de outras crianças de classe média. Do outro lado, o comprometimento em nutrir um desenvolvimento natural da criança gerava um sentimento emergente de restrição na vida de Harold McAllister e outras crianças de classe trabalhadora e pobre. (As conseqüências das práticas de criação dos filhos estão resumidas no Quadro 2.)

Tanto os pais quanto os filhos usavam os recursos associados a essas abordagens durante suas interações com os representantes das instituições. Pais e filhos de classe média adaptavam-se a cada interação; as famílias trabalhadoras e pobres tendiam a uma interação "genérica". Quando enfrentavam problemas, os pais de classe média pareceram mais preparados em exercer sua influência sobre outros adultos se comparados aos pais trabalhadores e pobres. Da mesma forma, os pais e crianças de 
classe média não demonstravam a mesma intimidação e confusão que testemunhamos entre as famílias trabalhadoras e pobres quando enfrentavam um problema na escolarização dos filhos.

\section{SINAIS EMERGENTES DE DIREITO}

A mãe de Alexander Williams, como várias mães de classe média, ensina, explicitamente, o filho a ser um cliente informado e assertivo em suas interações com profissionais. Por exemplo, enquanto leva Alexander para uma consulta de rotina no médico, ela o ensina a arte de comunicarse eficientemente em ambientes de saúde:

\footnotetext{
[Alexander pergunta se ele precisa tomar alguma vacina no médico. A senhora Williams diz que ele terá que perguntar ao médico. Quando entramos na Rua Park, a mãe diz calmamente a Alex]: Alexander, você deveria pensar no que quer perguntar ao médico. Você pode perguntar o que quiser. Não seja tímido. Pode perguntar qualquer coisa.

[Alexander pensa por um minuto e diz]: Eu tenho uns caroços debaixo do braço por causa do desodorante.

Mãe: Mesmo? Quer dizer do desodorante novo? Alex: É.

Mãe: Bom, você deve perguntar ao médico.
}

Alexander aprende assim que ele tem o direito de falar (ex.: "Não seja tímido") e que ele deve se preparar para um encontro com uma pessoa em posição de autoridade, organizando seus pensamentos com antecedência.

Esses recursos de classe são subseqüentemente ativados no encontro com o médico (um homem branco entre trinta e quarenta anos). O exame começa da seguinte forma: 
Médico: Ok, como sempre, gostaria de fazer as perguntas usuais. Se tiver alguma pergunta, vá em frente. [O médico examina o gráfico de Alex]: Com relação a altura, Alexander está no percentil de 95.

[Apesar de o médico estar falando com a senhora Williams, Alexander o interrompe]:

Alex: Estou no que?

Médico: Significa que você é mais alto do que noventa e cinco garotos quando eles têm, uh, dez anos.

Alex: Eu não tenho dez.

Médico: Bom, eles colocaram você no gráfico como se tivesse dez... Eles normalmente usam o ano mais próximo para fazer o gráfico.

Alex: Tá bom.

O "Tá bom" de Alexander revela que ele se sentia no direito de dar importância a seu próprio julgamento. Alguns minutos mais tarde, o exame é interrompido quando o médico tem que dar uma consulta de urgência ao telefone. Alexander ouve a conversa do médico e depois usa o que ouviu como base para uma clara diretiva:

\footnotetext{
Médico: Os pontos estão na pálpebra, há laceração?... Hmm... Eu não suturo pálpebras... Hmm... De jeito nenhum!... Não toque nelas. Isso foi um mau julgamento da parte do acampamento. [Desliga o telefone]. Desculpe a interrupção. Alex: Fique longe das minhas pálpebras!
}

O comentário de Alexander, que gera risada dos adultos, reflete sua tremenda naturalidade em interagir com o médico.

Mais tarde, a senhora Williams e o médico discutem a dieta de Alexander. Ela admite abertamente que eles nem sempre seguem as recomendações alimentares. Sua honestidade é uma forma de capital, pois dá ao médico as informações corretas de que necessita para fazer o diagnóstico. O fato de não sentirem necessidade de dissimular a realidade, faz com que a mãe e o filho tenham um cuidado médico melhor: 
Médico: Começemos com o apetite. Você come três refeições por dia?

Alex: Sim.

Médico: E agora uma pergunta importante. Você come frutas e vegetais também?

Alex: Sim

Mãe [em voz alta]: Ooooo...

Médico: Pelo jeito temos uma segunda opinião. [Risos]

Alex [falando mais alto]: Você me dá bananas e coisas assim todo dia no almoço. E eu comi repolho ontem a noite no jantar.

Médico: Você come pelo menos uma ou duas frutas, um ou dois vegetais, todos os dias?

Alex: Sim

Médico: Só um pouco?

Mãe: $98 \%$ do tempo ele come bem.

Médico: Ok, isso dá para o gasto...

Os recursos de classe são novamente utilizados quando a mãe de Alexander revela que ela "desistiu" da medicação. De forma agradável, mas firme, ele a instrui a continuar a medicação. Novamente, ele recebe informações precisas em vez de enfrentar uma posição de resistência silenciosa ou de desacato, como ocorrido em encontros entre os profissionais de saúde e outras famílias (principalmente trabalhadoras e pobres). O médico considera o poder relativo da senhora Williams: ele aconselha a continuar a medicação ao invés de mandá-la seguir o tratamento:

Mãe: As alergias dele acabaram de voltar. Tive que trazê-lo aqui uma vez este verão.

Médico: Estou vendo aqui uma anotação da doutora Svennson dizendo que ela o colocou nos medicamentos Vancinace e Benadril. Eles ajudaram?

Mãe: Um pouco, não muito. Então, eu dei o remédio por uma semana e depois, desisti.

[O médico senta-se mais perto]: Ok, eu vou aconselhá-la a não desistir. Se ele precisar, o 
Vancinance é um remédio muito eficiente. Mas demora pelo menos uma semana para fazer efeito...

Mãe: Ah, ok...

Médico: Eu preferiria que ele tomasse isso a medicamentos orais mais fortes. Você tem que dar o remédio por algumas semanas...

Um padrão similar de perguntas e respostas caracteriza a interação de Alexander com o médico, como mostra o seguinte fragmento:

Médico: A única coisa que você realmente precisa fazer depois do exame é checar, no andar de baixo... hmm... como estão seus olhos.

Alex: É! Eu adoro isso, eu adoro isso!

[O médico dá risadas]: Bom, agora a pergunta mais importante. Você tem alguma pergunta para me fazer antes de começar seu exame físico?

Alex: Hmm... só uma. Eu estou com uns caroços debaixo do braço, logo aqui. [Mostra o local]

Médico: Debaixo?

Alex: É

Médico: Ok... eles doem ou coçam?

Alex: Nenhum dos dois, eles só estão aí.

Médico: Ok, eu vou dar uma olhada nestes caroços para você. Hmm, que tal se você... Hmm...

Alex: Quase não tem mais nenhum

Médico: Ok, então, eu vou dar uma olhadinha... Alguma preocupação da sua parte? [Olhando para a mãe]

Mãe: Não... ele parece estar se desenvolvendo muito bem. ${ }^{34}$

O último comentário da mãe de Alexander reflete sua visão como um projeto, que é "estar se desenvolvendo muito bem". Ao longo da visita, ela demonstra naturalidade e percepção da consulta como uma

\footnotetext{
34 Nem todos os profissionais pediam a participação das crianças. Independentemente das atitudes gerais dos adultos, percebemos que as mães de classe média monitoravam e interferiam nas interações das crianças com os profissionais.
} 
troca entre pares (considerando Alexander um participante legítimo), ao invés de uma comunicação entre uma pessoa com autoridade e seus subordinados. Outros pais de classe média pareciam igualmente confortáveis. Durante a consulta de Garrett Tallinger, sua mãe tirou as sandálias e sentou em cima das pernas na sala de exames. Ela também, casualmente, brincou com o médico.

Os pais e as crianças de classe média também eram assertivos em situações ocorridas na escola de ensino fundamental na qual a maioria estudava. Houve diversos conflitos, pequenos e grandes, durante o ano. Por exemplo, os pais reclamavam entre si e com os professores sobre a quantidade de deveres de casa. Uma mãe negra de classe média, cuja filha não passou no teste de admissão para o programa de superdotados da escola, negociou para que fossem aceitos os resultados (mais elevados) obtidos pela filha em um outro teste realizado por uma empresa privada. Os pais de um menino da $4^{a}$ série envolveram o superintendente da escola em uma batalha sobre a letra de uma das músicas que seria apresentada durante a apresentação de Natal. O superintendente consultou o advogado do distrito escolar, que "aconselhou" o diretor a ser mais sensível, e a música não foi utilizada.

Da mesma forma, as crianças se afirmavam na escola. Exemplos disso incluem pedidos para que as cortinas fossem abaixadas para que o sol não ficasse nos olhos, cansar a professora para que tivesse permissão de refazer uma prova de matemática, na esperança de conseguir notas mais altas, e exigir saber por que ninguém guardou um pedaço de bolo durante uma festa da qual não pode participar. Nesses encontros, as crianças não apenas obedeciam aos pedidos dos adultos ou repetiam uma experiência anterior. Eles demonstravam um sentimento emergente de direito, encorajando os adultos a acomodarem os processos institucionais a suas preferências e necessidades. 
Obviamente, algumas crianças (e pais) eram mais fortes que outros ao lidar com os professores, alguns de forma mais bem-sucedida que outros. A mãe de Melanie Handlon, por exemplo, adotou uma abordagem muito participativa ao encarar os problemas de aprendizagem da filha, ela acompanhava diariamente todos os deveres de Melanie. Todavia, em vez de melhorar as notas, o único resultado foi um ambiente familiar deteriorado, marcado por tensões e lágrimas.

\section{SINAIS EMERGENTES DE RESTRIÇÃO}

As interações que observamos entre os profissionais e os pais trabalhadores e pobres pareciam, freqüentemente, cuidadosas e constritas. Este desconforto ficou evidente, por exemplo, durante o exame médico que Harold McAllister fez antes de ir para o acampamento bíblico. A mãe de Harold, normalmente tempestuosa e falante, ficou calada. Ao contrário da senhora Williams, ela parecia resistente em dar as informações corretas ao médico:

Médico: Ele come alguma coisa todo o dia - peixe, carne ou ovo?

[A mãe responde baixo e abafado]: Sim.

[O médico tenta olhar nos seus olhos, mas a mãe olha fixamente para um papel]: Algum vegetal amarelo?

Mãe [ainda sem olhar nos olhos, mirando o chão]: É!

Médico: Um vegetal verde?

[Mãe, olhando para o médico]: Nem sempre.

[O pesquisador de campo, desde que iniciou as visitas, não viu nenhuma das crianças comerem vegetais amarelos ou verdes.]

Médico: Não? Fruta ou suco?

[Mãe responde em voz baixa, sem quase olhar para o médico, olhando para o papel que ele está escrevendo]: Humm... humm...

Médico: Ele bebe leite todos os dias?

[A mãe responde de forma abrupta com tom de 
voz consideravelmente mais alto]: Sim!

Médico: Cereal, pão, arroz, batata, alguma coisa assim?

[A mãe balança a cabeça]: Sim, com certeza. [Olha para o médico.]

O conhecimento da senhora McAllister sobre o desenvolvimento de Harold não é uniforme. Ela não tem certeza de quando ele começou a andar e nem se lembra do nome do último médico. O médico então pergunta: "Quando foi a última vez que ele tomou uma vacina antitetânica?"; ela reage bruscamente: "O que é uma vacina antitetânica?"

[Ao contrário da senhora Williams, que pediu a Alexander para repartir informações com o médico, a senhora McAllister silencia as tentativas de Aléxis:]

Médico: Alguma marca de nascença?

[Mãe olha para o médico, balança negativamente a cabeça.]

[Alexis, levantando o braço esquerdo, diz animadamente:] Eu tenho uma marca de nascença debaixo do braço!

Mãe [aumentando o volume da voz e parecendo severa]: Dá para se acalmar um minuto? Mãe [novamente respondendo a pergunta do médico]: Não.

Apesar da tensão e da profunda mudança de comportamento da senhora McAllister, a consulta de Harold não é desconfortável. Além disso, a mãe de Harold não é constantemente tímida e passiva. Antes de a consulta começar, o médico entra na sala de espera e chama Harold. Em resposta, a família McAllister (e o pesquisador) se levanta. A senhora McAllister então chama o sobrinho Tyrice (que tem quase a mesma idade de Harold) para entrar na sala junto com eles, antes mesmo de perguntar ao médico se poderia. Depois, ela manda Tyrice seguir o corredor para observar Harold sendo pesado; ela conta com o relatório do sobrinho, em vez de se informar com os profissionais da saúde. 
Mesmo assim, nem Harold nem sua mãe, pareciam tão confortáveis como Alexander. Alexander estava acostumado a conversar longamente em casa; com o médico ele fazia perguntas com naturalidade. Harold, que estava acostumado em casa a responder a diretivas, basicamente respondia às perguntas do médico, e não fazia suas próprias perguntas. Alexander, encorajado pela mãe, foi assertivo e confiante com o médico. Harold foi reservado. Ao perceber a necessidade aparente da mãe em esconder a verdade sobre o tipo de comida que consumia, ele parecia cauteloso, demonstrando um sentimento emergente de restrição.

Observamos um padrão similar nas interações escolares. De maneira geral, os adultos trabalhadores e pobres eram muito mais distantes da escola do que os de classe média. A senhora McAllister, por exemplo, podia ser bem assertiva em algumas situações (ex.: no começo das observações familiares ela visitou o traficante local, alertando-o a não "mexer" com o pesquisador negro). ${ }^{35}$ Todavia, durante a reunião de pais da $4^{a}$ série, ela manteve seu casaco totalmente fechado, sentou-se curvada na cadeira e falou em tom quase inaudível. Ela ficou muito surpresa quando a professora disse que Harold não estava fazendo os deveres de casa. Chocada ela disse: "Ele faz em casa". A professora negou e continuou falando. A senhora McAllister não fez mais nenhum comentário e não pediu outras informações, exceto sobre uma carta que a professora disse ter enviado a sua casa e que ela não havia recebido. A reunião terminou oferecendo à senhora McAllister poucas informações sobre a experiência educacional de Harold. ${ }^{36}$

35 A senhora McAllister nos contou sobre esta visita; não a observamos. É interessante notar que ela considerou apenas o pesquisador negro como estando em risco.

36 Os pais de classe média, por vezes, pareciam um pouco ansiosos durante as reuniões de pais e mestres, mas, no geral, eles falavam mais e faziam mais perguntas do que os pais pobres e trabalhadores. 
Outros pais trabalhadores e pobres também pareciam confusos, intimidados e subjugados durante as reuniões de pais e mestres. A senhora Driver, que estava muito preocupada com a falta de habilidade de ler da filha na $4^{a}$ série, guardou as preocupações para ela mesma. Ela nos explicou: "Eu não quero dizer algo e depois descobrir que estava errada.” Quando os pais trabalhadores e pobres tentavam intervir nas experiências educacionais dos filhos, eles se sentiam inúteis. A mãe de Billy Yanelli parecia relaxada e falante com outros adultos. Contudo, com "a escola" ela era apreensiva. Ela se sentia intimidada e sem poder. Esperando resolver um problema do filho, tentou preparar suas idéias com antecedência. Mesmo assim, como nos contou em uma entrevista, ela falhou ao tentar convencer o pessoal da escola que o filho estava vulnerável:

Senhora Yanelli: Eu achei, um dia, um recado na mochila dele que dizia: "Eu vou te matar... você é um filho da p....". Eu comecei a tremer. Eu estava pronta para ir lá. [Eu estava] preparada para falar com a psicóloga da escola... Eles disseram que eles [as outras crianças] fazem o que fazem porque o Billy faz com que eles façam isso. Eles tinham uma resposta para tudo.

Entrevistador: O que você achou da resposta?

Senhora Yanelli: Eu odeio a escola. Odeio!

As crianças de família trabalhadora e pobre pareciam estar conscientes dessa frustração dos pais e testemunhavam esse sentimento de falta de poder. Billy Yanelli, por exemplo, afirmou em uma entrevista que a mãe "odeia" o pessoal da escola.

Por vezes, esses pais encorajavam os filhos a resistirem à autoridade da escola. A família Yanelli disse a Billy para bater em um garoto que o estava incomodando. A mãe de Wendy Driver a aconselhou a esmurrar um colega que puxava seu rabo-de-cavalo. $\mathrm{O}$ namorado da mãe acrescentou: "Bate nele quando a professora não estiver olhando". 
Durante as observações de sala de aula, os alunos de família trabalhadora e pobre podiam ser animados e enérgicos, mas não tentavam adaptar seu ambiente. Eles tendiam a reagir às ofertas dos adultos ou, algumas vezes, a implorar aos educadores que repetissem alguma experiência prévia, tais como ler uma história específica, ver um filme ou ir para o laboratório de computação. Se compararmos com as interações das crianças de classe média, os limites entre os adultos e as crianças pareciam mais claros e delimitados. Apesar de muitas vezes resistirem e testarem as regras da escola, as crianças não pareciam querer que os educadores acomodassem suas preferências individuais.

De maneira geral, o comportamento dos pais de classe trabalhadora e pobre não pode ser explicado como uma manifestação de seu temperamento ou como uma completa passividade; os pais eram um tanto enérgicos em suas interferências em outras esferas da vida dos filhos. Os pais trabalhadores e pobres pareciam depender da escola (Lareau, 2000a), mesmo quando tinham dúvidas quanto à confiabilidade dos profissionais. Essa suspeita com relação aos profissionais das instituições dominantes é, ao menos em algumas instâncias, uma resposta pertinente. ${ }^{37} \mathrm{O}$ nível desigual de confiança, assim como as diferenças na quantidade de informações divulgadas, podem gerar lucros desiguais em um momento histórico no qual os profissionais aplaudem a assertividade e rejeitam a passividade como uma forma inapropriada de criação dos filhos (Epstein, 2001). Pais e filhos de classe média normalmente, mas não sempre, ampliam com seus esforços as vantagens ou benefícios. Alexander Williams conseguiu que o médico levasse a sério suas preocupações de saúde. Os filhos da senhora Marshall acabaram entrando

37 Os altos índices de relatos institucionais relativos à negligência infantil, abuso de crianças e outras dificuldades familiares entre as famílias pobres pode refletir a maior vulnerabilidade deste grupo frente as intervenções institucionais (ver L.Gordon, 1989). 
no programa para crianças superdotadas, apesar de, tecnicamente, não se qualificarem. As crianças de classe média esperam que as instituições respondam a eles e acomodem suas necessidades individuais. Ao contrário, quando ensinam Wendy Driver a bater no garoto que a está incomodando (sem que a professora veja) ou quando dizem a Billy Yanelli para se defender fisicamente, mesmo indo contra as regras da escola, eles não estão aprendendo como tirar vantagem da burocracia institucional. Ao invés disso, estão aprendendo a se sentirem frustrados e sem poder.

\section{POR QUE A CLASSE SOCIAL FAZ DIFERENÇA?}

Os recursos econômicos dos pais ajudam a definir as diferenças de classe nas práticas de criação dos filhos. As mensalidades dos cursos, que os pais de classe média consideravam insignificantes, eram muito caras para as famílias menos afortunadas. Os pais também pagavam por roupas, equipamentos, diárias de hotel, refeições em lanchonetes, acampamentos de verão e eventos para angariar fundos. Em 1994, o custo estimado pela família Tallinger com as atividades de Garrett era de U\$4.000 por ano, e este valor não foi atipicamente alto. ${ }^{38}$ Além disso, as famílias precisavam de transporte particular confiável e horário de trabalho flexível para levar e trazer os filhos durante esses eventos. Esses recursos estavam concentrados, desproporcionalmente, nas famílias de classe média.

As diferenças de recursos educacionais também foram importantes. Os níveis educacionais superiores dos pais de classe média os deram maior vocabulário facilitando um cultivo orquestrado, particularmente em intervenções institucionais. Os pais trabalhadores e

\footnotetext{
38 Em 2002, as despesas com apenas um esporte eram de mais de U\$5.000 por ano. Os gastos com campeonatos de hóquei no gelo giram em torno de U\$2.700; os custos com equipamentos também são altos (Halbfinger, 2002).
} 
pobres não tinham familiaridade com os termos-chaves usados pelos profissionais, tais como "vacina antitetânica". As bases educacionais dos pais de classe média também os davam confiança ao criticar os profissionais da educação e intervir nos assuntos escolares. Os pais trabalhadores e pobres viam os educadores como socialmente superiores. Kohn e Schooler (1983) mostraram que a profissão dos pais, especialmente a complexidade de seus trabalhos, influenciava suas crenças sobre a forma de se criar os filhos. Descobrimos que o trabalho dos pais fazia diferença, mas também vimos que as experiências dos adultos influenciavam os conceitos de infância. Os pais de classe média freqüentemente se preocupavam com os prazeres e desafios em suas vidas profissionais. ${ }^{39}$ Eles tendiam a ver a infância como uma oportunidade dupla: um momento para brincar e também para desenvolver seus talentos e habilidades que possam ter valor em suas vidas futuras. $\mathrm{O}$ senhor. Tallinger afirmou que jogar futebol ajudava Garrett a ser "pragmático" e "competitivo", habilidades importantes no local de trabalho. A senhora Williams mencionou a importância de Alexander aprender como trabalhar com os outros enquanto participava de esportes coletivos. Os pais de classe média, conscientes do "declínio de fortuna" da classe média, preocupavam-se com seu futuro econômico e de seus filhos (Newman, 1993). Essa incerteza aumentou o compromisso em ajudar os filhos a desenvolverem habilidades amplas para aumentar suas possibilidades futuras.

A concepção do mundo adulto e da infância entre os pais trabalhadores e pobres também parecia estar intimamente ligada a suas próprias experiências. Para a classe trabalhadora, o trabalho sem

\footnotetext{
39 Os adultos de classe média não tinham uma vida livre de problemas, mas, se comparados com os trabalhadores e pobres, eles tinham experiências ocupacionais mais variadas e maior acesso a trabalhos com retorno econômico mais elevado.
} 
perspectivas e a pressão da carência econômica definiam sua experiência como adultos e influenciavam sua visão da infância. A visão dos pais pobres era definida pela dependência da assistência pública e pela falta severa de recursos econômicos. As famílias de ambas as classes tinham preocupações com questões básicas: falta de alimentos, acesso limitado a serviços de saúde, segurança física, transporte não confiável, carência de roupas. Ao olhar para suas próprias infâncias, esses pais se lembravam dos sofrimentos, mas também de momentos sem as ansiedades que enfrentavam no presente. Muitos deles queriam que os filhos se concentrassem em serem felizes e sem problemas, deixando os fardos da vida de lado até que fossem mais velhos.

Dessa forma, as estratégias de criação são influenciadas por mais do que a educação dos pais, estando inter-relacionadas com suas experiências de vida e seus recursos, incluindo fontes econômicas, condições ocupacionais e passado educacional. Isso parece ser o mais importante ao guiar os pais de classe média a um cultivo orquestrado, e os pais trabalhadores e pobres a um crescimento natural. Mesmo assim, a localização estrutural da família não determinava por completo as práticas de criação dos filhos. A interferência dos atores e a indeterminância da vida social são inevitáveis.

Além dos recursos sociais e econômicos, quais os outros fatores significantes? Se os recursos das famílias trabalhadoras e pobres fossem transformados de um dia para o outro, de forma que fossem os mesmos das famílias de classe média, haveria também uma mudança na lógica de criação dos filhos? Ou há crenças e atitudes culturais que são substancialmente independentes dos recursos econômicos e sociais que influenciaram as práticas dos pais? O tamanho e escopo deste estudo impedem uma resposta definitiva. Alguns pais de classes trabalhadora e pobre adotavam princípios do cultivo orquestrado: eles queriam (mas não podiam pagar) que seus filhos participassem de atividades organizadas 
(ex.: aulas de piano, de canto), acreditavam ser importante ouvi-los e se envolviam na escolarização deles. No entanto, mesmo quando pais das diferentes classes sociais pareciam ter princípios similares, suas motivações eram diferentes. Por exemplo, muitos pais trabalhadores e pobres queriam mais atividades para seus filhos a fim de oferecer-lhes um local seguro. Seu objetivo era a proteção contra o perigo, e não propriamente uma chance de cultivar o talento dos filhos.

Alguns pais criticavam explicitamente os horários das crianças que se envolviam com muitas atividades. Durante a entrevista com os pais, descrevemos as atividades reais de duas crianças (usando informações das 12 famílias que observamos). Um desses horários era parecido com o de Alexander Williams: televisão restrita, leitura obrigatória e muitas atividades organizadas, incluindo aulas de piano (por motivos analíticos, dissemos que, ao contrário de Alexander, a criança não gostava das aulas de piano, mas os pais não o deixavam desistir). Resumindo a atitude dos pais trabalhadores e pobres frente a esse tipo de horário, ${ }^{40}$ uma mãe branca pobre reclamou: "Eu acho que ele quer mais. Acho que metade do tempo ele não gosta de fazer o que faz [risos]. Eu acho que os pais são muito severos. E que ele não é criança." Mesmo os pais que acreditavam que esta abordagem mais dominante geraria frutos futuros no "mercado de trabalho", expressaram sérias reservas: "Acho que ele é uma criança triste" ou "Ele deve ficar cansado pra burro".

Sendo assim, pais pobres e trabalhadores tinham crenças variadas. Alguns queriam um horário com atividades organizadas para seus filhos, outros não; alguns acreditavam na racionalização e em ter um papel ativo na escolarização dos filhos, ao contrário de outros. Compreender

\footnotetext{
40 Muitos pais de classe média achavam errado forçar uma criança a ter aulas de piano contra sua vontade. No entanto, continuaram a reforçar a importância da "exposição".
} 
completamente os efeitos dos recursos materiais e culturais nas escolhas dos pais e dos filhos é um desafio para pesquisas futuras. ${ }^{41}$

\section{DISCUSSÃO}

A evidência mostra que a posição da família influencia aspectos fundamentais da vida familiar: uso do tempo, uso da linguagem e laços familiares. Nem todos os aspectos são afetados pela classe social e há variabilidade em cada classe. Mesmo assim, os pais transmitem vantagens a seus filhos em padrões suficientemente consistentes e identificáveis para serem descritos como uma "lógica cultural" de criação dos filhos. Os pais negros e brancos de classe média empregavam o que denominei "cultivo orquestrado" - eles faziam um esforço deliberado e contínuo para estimular o desenvolvimento dos filhos e para cultivar suas habilidades cognitivas e sociais. Os pais trabalhadores e pobres viam o desenvolvimento dos filhos como um florescer espontâneo, desde que fosse dado um apoio básico, como conforto, comida, abrigo etc. Esse comprometimento também requeria um esforço contínuo: manter o crescimento natural dos filhos, apesar de grandes desafios, pode ser certamente considerado um feito.

\footnotetext{
41 Da mesma forma, é impossível determinar, através dos achados deste estudo, se o cultivo orquestrado e o crescimento natural são novos desenvolvimentos históricos ou modificações de formas anteriores de criação dos filhos. A "institucionalização do lazer infantil" parece estar crescendo (Corsaro,1997). Hays (1996) argumenta que as famílias, cada vez mais, estão sendo invadidas pela "lógica das relações impessoais, competitivas, contratuais, mercadológicas, eficientes, lucrativas e interesseiras" (pg.11). Além da evidência do crescimento das atividades organizadas para crianças (Sandberg e Hofferth, 2001), nenhum dos pais de classe média relatou ter tido, quando crianças, um horário parecido com o dos filhos. É difícil determinar com precisão a mudança temporal das interferências dos pais na educação e a quantidade de racionalização nas famílias de classe média. O estudo de Kohn e Schooler (1983) sugere pouca mudança com relação à racionalização, mas outros insistem em dizer que houve um aumento no nível de negociação entre pais e filhos (Chidekel, 2002; Kropp, 2001). Esses debates não podem ser resolvidos sem que haja uma pesquisa histórica cuidadosa.
} 
$\mathrm{Na}$ vida diária, os padrões associados a cada uma dessas abordagens se misturam e se reforçavam mutuamente. As crianças de classe média, aos nove anos, já reconheciam claramente seus próprios talentos e habilidades, diferenciando-se de seus irmãos e amigos. Eles também aprendiam a pensar em si mesmos como especiais e merecedores de todo o tempo e energia que os adultos gastavam para estimulá-los. Neste processo, os limites entre adultos e crianças são, por vezes, embaçados; o lazer dos adultos fica subordinado ao de seus filhos. A ênfase maior na racionalização em famílias de classe média teve um efeito similar. As crianças usavam suas incríveis habilidades de racionalização para persuadir os adultos a fazerem suas vontades. A idéia de que os desejos dos filhos deveriam ser considerados seriamente foi muito notada durante as entrevistas e observações. De forma muito sutil, as crianças foram ensinadas a se sentir como possuidora de direitos. Finalmente, o comprometimento em "cultivar" os filhos resultava em um horário familiar tão cheio de atividades que não sobrava tempo para visitar os parentes. Estudos quantitativos sobre o uso do tempo iluminam questões importantes, mas não revelam a natureza interativa da rotina, as atividades do dia-a-dia e as diversas formas como estas afetam o tecido da vida familiar. ${ }^{42}$

Em famílias trabalhadoras e pobres os pais estabeleciam limites; dentro desses limites, as crianças eram livres para decidir como passar seu tempo livre. Os desejos infantis não guiavam as ações dos adultos tão freqüentemente, ou tão decisivamente, como acontecia nas casas de classe

\footnotetext{
42 As diferenças de uso do tempo que observamos eram aspectos ignorados na vida diária; elas normalmente não eram notadas pelos membros da família. Por exemplo, a família trabalhadora Yanelli se considerava "muito ocupados" se tinham um jogo de beisebol no sábado e um encontro com a família estendida no domingo. A família Tallinger, assim como outras de classe média, considerariam calmo este final de semana.
} 
média. As crianças eram vistas como subordinadas aos adultos. Os pais tendiam a usar mais diretivas do que negociações. As freqüentes interações com os parentes, em vez de conhecidos ou estranhos, criavam uma divisão mais profunda entre as famílias e o mundo exterior. Implícita e explicitamente, os pais ensinavam os filhos a manter distância de pessoas que ocupavam posições de autoridade, a desconfiarem das instituições e, por vezes, a resistir à autoridade oficial. As crianças pareciam absorver o sentimento de impotência dos pais em suas relações institucionais. Assim como na classe média, houve variações importantes entre as classes trabalhadoras e pobres, e alguns aspectos críticos da vida familiar, tais como o uso do humor, eram imunes à classe social.

O papel da raça na vida diária das crianças foi menos importante do que esperávamos. Os pais negros de classe média estavam conscientes dos possíveis efeitos de uma discriminação institucional sobre os filhos, tomando medidas para ajudá-los a desenvolverem uma identidade racial positiva. Mesmo assim, considerando como os filhos passavam o tempo, como os pais usavam a língua, a disciplina dentro de casa, a natureza dos laços familiares e as estratégias usadas para interferir nas instituições, os pais brancos e negros de classe média utilizavam-se de práticas similares e muitas vezes idênticas. Um padrão parecido foi observado nas famílias trabalhadoras brancas e negras, assim como nas famílias pobres brancas e negras. Sendo assim, meus dados indicam que, dentro da dinâmica de criação estudada, a raça teve menos importância do que a classe social na vida diária das crianças. ${ }^{43}$ Ao entrar em mundos segregados racialmente, como nos namoros, casamentos, mercado imobiliário, e quando se

\footnotetext{
43 Estas descobertas são compatíveis com as de outros que mostram que as crianças tem consciência de raça com, relativamente, pouca idade (Van Ausdale e Feargin,1996). Nos dois locais, as meninas costumavam brincar em grupos segregados racialmente durante o recreio; já os meninos tendiam a brincar em grupos integrados racialmente.
} 
depararem com um maior grau de racismo em seus contatos interpessoais (Waters, 1999), a importância relativa da raça tende a diminuir.

A lógica de criação dos filhos e as diferenças na dinâmica familiar entre as classes têm conseqüências em longo prazo. Quando os membros da família saíam de casa e interagiam com representantes das instituições formais, os pais e filhos de classe média sabiam negociar por resultados mais rentáveis do que suas contrapartes trabalhadoras e pobres. Nas interações com agentes das instituições dominantes, os filhos de trabalhadores e pobres aprendiam a se sentirem constrangidos, enquanto os filhos de classe média desenvolviam um sentimento de direito.

É um erro considerar como intrinsecamente desejável qualquer uma das abordagens (cultivo orquestrado ou crescimento natural). Como vem sendo amplamente divulgado, as concepções de infância sofrem mudanças drásticas ao longo do tempo (Wrigley, 1989). As desvantagens da criação de classe média, incluindo a exaustão, associada a uma maternidade intensiva, os horários familiares frenéticos, além da destruição da ingenuidade das crianças, que as fazem se sentir muito sofisticadas para brinquedos e jogos simples (Hays, 1996), ainda não foram suficientemente aclaradas.

Outra desvantagem é que as crianças de classe média tendem a saber menos como preencher o "tempo vazio" com suas próprias brincadeiras, levando-os a depender dos pais para solucionar as experiências de tédio. Os sociólogos precisam diferenciar mais claramente os níveis que são intrinsecamente desejáveis e aqueles que facilitam o sucesso nas instituições dominantes. Uma visão mais crítica e historicamente sensível é desejável (Donzelot, 1979). O trabalho de Bourdieu (1976, 1984, 1986,1989) é, assim, precioso.

Finalmente, há questões metodológicas a serem consideradas. A pesquisa quantitativa delineia grandes padrões populacionais; a etnografia oferece um rico detalhamento descritivo, mas, normalmente, focaliza-se 
em um pequeno grupo. Nenhuma das abordagens pode oferecer uma avaliação holística, mas baseada empiricamente, da vida cotidiana. Uma pesquisa etnográfica em diferentes locais e com diferentes pessoas leva a desafios metodológicos formidáveis (Lareau, 2002). Mesmo assim, as famílias se mostraram abertas a serem estudadas de forma tão íntima. Criar retratos profundos da vida familiar que enriqueçam nossos modelos teóricos é um importante desafio para o futuro.

\section{REFERÊNCIAS}

ARIES, Philippe. 1962. Centuries of Childhood: A Social History of the Family. Translated by R. Baldick. London, England: Cape.

BERNSTEIN, Basil. 1971. Class, Codes, and Control: Theoretical Studies towards a Sociology of Language. New York: Schocken Books.

BIANCHI, Suzanne M. 2000. "Maternal Employment and Time with Children: Dramatic Change or Surprising Continuity". Demography, 37, p. 401-414.

BIANCHI, Suzanne and John Robinson. 1997. "What Did You Do Today? Children's Use of Time, Family Composition, and Acquisition of Social Capital". Journal of Marriage and the Family, 59, p. 332-344.

BOURDIEU, Pierre. 1976. "Marriage Strategies as Strategies of Social Reproduction”. p. 117-144. In: Family and Society, edited by R.Foster and O.Ranun. Baltimore, MD: John Hopkins University Press.

BOURDIEU, Pierre. 1984. Distinction: A Social Critique of the Judgment of Taste. Cambridge, MA: Havard University Press.

BOURDIEU, Pierre. 1986. "The Forms of Capital". p. 241-58. In: Handbook of Theory and Research for the Sociology of Education, edited by J.C.Richardson. New York: Greenwood.

BOURDIEU, Pierre. 1989. The State Nobility: Elite Schools in the Field of Power. Standford, CA: Standford University Press.

BRONFENBRENNER, Urie. 1966. "Socialization and Social Class 
through Time and Space”. p. 362-377. In: Class, Status and Power, edited by R.Bendix and S.M.Lipset. New York: Free Press.

BURAWOY, Michael, Alice Burton, Ann Arnett Ferguson, and Kathryn J.Fox, ed. 1991. Ethnography Unbound: Power and Resistance in the Modern Metropolis. Berkeley, CA: University of California Press.

CHIDEKEL, Dana. 2002. Parents in Charge. New York:Simon and Schuster.

CONLEY, Dalton. 1999.Being Black, Living in the Red, Race, Wealth, and Social Policy in America. Berkeley, CA: University of California Press.

CORSARO, William A. 1997. The Sociology of Childhood. Thousand Oaks. CA:Pine Forge.

CROUTER, Ann C., Heather Helms-Erikson, Kimberly Updegraff, and Susan M. McHale.1999. “Conditions Underlying Parents' Knowledge about Children's Daily Lives in Middle Childhood: Between- and withinFamily Comparisons.” Child Development, 70, p. 246-259.

DALEY, Kerry J. 2001. "Deconstructing Family Time: From Ideology to Lived Experience." Journal of Marriage and the Family, 62, p. 238-294.

DONZELOT, Jacques. 1979. The Policing of Families. Translated by R.Hurley. New York: Pantheon.

EPSTEIN, Joyce. 2001. Schools, Family and Community Partnerships. Boulder,CO: Westview.

ERIKSON, Robert, and John H.Goldthorpe. 1993. The Constant Flux: A Study of Class Mobility in Industrial Societies. Oxford, England: Claredon.

FISCHER, Claude. 1982. To Dwell among Friends. Chicago: University of Chicago Press.

FORDHAM, Signithia. and John U. Ogbu. 1986. "Black Students' School Success:Coping with the burden of Acting White". The Urban Review, 18, p. 176-206.

GORDON. Linda. 1989. Heores of Their Own Lives: The Politics and History 
of Family Violence. New Yorl: Penguin.

HALBFINGER, David M. 2002. “A Hockey Parent's Life: Time, Money and Yes, Frustration". New York Times, January 12, p. 29.

HART, Betty and Todd Risley. 1995. Meaningful Differences in the Everyday Experience of Young American Children. Baltimore, MD: Paul Books.

HAYS, Sharon. 1996. The Cultural Contradictions of Motherhood. New Haven,CT: Yale University Press.

HEATH, Shirley Brice. 1983. Ways with Words. London, England: Cambridge University Press.

HEIMER, Carol A. and Lisa Staffen. 1998. For the Sake of the Children: The Social Organization of Responsibility in the Hospital and at Home. Chicago, IL: University of Chicago Press.

HERTZ, Rosanna and Nancy L. Marshall, (Ed.). 2001. Working Families: The Transformation of the American Home. Berkeley, CA: University of California Press.

HESS, Robert and Gerald Handel. 1974. Family Worlds: A Psychosocial Approach to Family Life. Chicago, IL: University of Chicago Press.

HOCHSCHILD, Arlie Russel. 1989. The Second Shift: Working Parents and the Revolution at Home. New York: Viking.

HOFFERTH, Sandra L. 1999. " Family reading to Young Children: Social Desirability and Cultural Biases in Reporting" (Relatório de estudo $\mathrm{n}^{\circ}$ 005-99, Maio 13, 1999) Institute for Survey research, center for Ethnography of Everyday Life, University of Michigan, Ann Arbor, MI. <http://ceel.psc.isr.umich.edu/pubs/papers/ceel005-99.pdf>.

HOFFERTH, Sandra and John Sandberg. 2001a. "Changes in American Children's Time, 1981-1997." Pp. 193-232 in Advances in Life Course Research, vol. 6, Childern at the Millenium: Where Have We Come From, Where Are We Going?" edited by S. Hofferth and T.Owens. Oxford, England, Eslevier Science Lts.

HOFFERTH, Sandra and John Sandberg. 2001b. "How American 
Children Spend Their Time" Journal of Marriage and the Family, 63, p. 293308.

JACOBS, Jerry and Kathleen Gerson. 1998. "Who Are the Overworked Americans?" Review of Social Research, 56, p. 442-459.

JUSTER, F. Thomas and Frank P. Stafford (Ed.). 1985. Time, Goods, and Well-Being. Ann Arbor, MI: Survey Research Center, Institute for Social Research.

KINGSTON, Paul. 2000. The Classless Society. Stanford, CA: Stanford University Press.

KOHN, Melvin and Carmi Schooler (Ed.). 1983. Work and Personality: An Inquiry into the Impact of Social Stratification. Norwood, NJ: Ablex.

KROPP, Paul. 2001. I'll Be The Parent, You Be the Child. New York: Fisher Books.

LAMONT, Michele. 2000. The Dignity of Working Men: Morality and the Boundaries of Race, Class, and Immigration. Cambridge, MA: Harvard University Press.

LAREAU, Annette. 2003. Unequal Childhood: Class, Race, and Family Life. Berkely, CA: University of California Press.

LAREAU, Annette. 2002. "Doing Multi-Person, Multi-Site 'Ethnographic' Work: A Reflective, Critical Essay”. Department of Sociology, Temple University, Philadelphia, PA. Manuscrito não publicado.

LAREAU, Annette. 2000. Home Advantage: Social Class and Parental Intervention in Elementary Education. 2. ed. Lanham, MD: Rowman and Littlefield.

LAREAU, Annette. 2000b. "My Wife Can Tell Me Who I Know: Methodological and Conceptual Issues in Studying Fathers." Qualitative Sociology, 23, p. 407-433.

LEVER, Janet. 1988. "Sex Differences in the Complexity of Children's Paly and Games" Pp.324-44 in Childhood Socialization, edited by G. Handel. 
New York: Aldine de Gruyter.

MARSIGLIO, William. 1991. "Paternal engagement Activities with Minor Children". Journal of Marriage and the Family, 53, p. 973-986.

MASSEY, Douglas and Nancy Denton. 1993. American Apartheid. Cambridge, MA: Harvard University Press.

McLANAHAN, Sara and Gary Sandefur. 1994. Growing up With a Single Parent. What Hurts, What Helps. Cambridge, MA: Harvard University Press.

MEDRICH, Elliot, Judith Roizen, Victor Rubin, and Stuart Buckley. 1982. The Serious Business of Growing Up. Berkley, CA: University of California Press.

MENAGHAN, Elizabeth G. 1991. "Work Experiences and Family Interaction Processes: The Long Reach of the Job?" Annual Review of Sociology, 17, p. 419-444.

NEWMAN, Kathleen. 1993. Declining Fortunes: The Withering of the American Dream. New York: Basic Books.

PATILLO-McCoy, Mary. 1999. Black Picket Fences: Privilege and Peril among the Black Middle-Class. Chicago, IL: University of Chicago Press. PRESSER, Harriet B. 1989. "Can We Make Time for Children? The Economy, Work Schedules, and Child Care.” Demography, 26, p. 523-543.

ROBINSON, John P. And Geoffrey Godbey. 1997. Time for Life: The Surprising ways Americans Use Their Time. University Park, PA: The Pennsylvania State Press.

RUBIN, Lilian. 1976. Worlds of Pain: Life in a Working-Class Family. New York: Basic Books.

SANDBERG, John F. and Sandra L. Hofferth. 2001. Changes in Children's Time with Parents, U.S., 1981-1997”. Demography, 38, p. 423436.

SHEHAN, Constance L. (Ed.). 1999. Through the eyes of the Child: ReVisioning Children as Active Agents of Family Life. New York: JAI Press. 
SCHEMARI, James. 2002. "Practices Makes Perfect (and Poorer Parents)". The New York. Times, January 27, p. 11.

SKOLNICH, Arlene. 1991. Embattled Paradise: The American Family in an Age of Uncertainty. New York: Basic Books.

TATUM, Beverly Daniel. 1997. Why Are All the Black Kids Sitting Together in the Cafeteria? And Other Conversations about Race. New York: Basic Books. THOMPSON, Shona M. 1999. Mother's Taxi: Sport and Women's Labor. Albany, Y: SUNY Press.

THORNE, Barrie. 2001. "Growing Up in Oakland: Orbits of Class, 'Race', and Culture'. Trabalho apresentado no encontro anual da Associação Americana de Sociologia, 19 de Agosto, Anaheim, CA.

VAN AUSDALE, Debra and Joe R. Feagin. 1996. "Using Racial and Ethnic Concepts: The Critical Case of Very Young Children”. American Sociological Review, 61, p. 779-793.

WAKSLER, Frances. 1991. Studying the Social Worlds of Children. Bristol, England: Falmer.

WATERS, Mary. 1999. Black Identities: West Indian Immigrant Dreams and American Realities. New York: Russel Sage Foundation.

WRIGHT, Erik Olin. 1997. Class Counts: Comparative Studies in Class Analysis. Cambridge, England: Cambridge University Press.

WRINGLEY, Julia. 1989. "Do Young Children Need Intellectual Stimulation? Experts' Advice to Parents, 1900-1985”. History of Education, 29, p. 41-75.

ZELIZER, Vivianna. 1985. Pricing the Priceless Child: The Changing Social Value of Children. New York: Basic Bookks.

ZICK, Cathleen D. And W. Keith Byrant. 1996. "A New Look at Parents' Time Spent in Child Care: Primary and Secondary Time Use." Social Science Research, 25, p. 260-280. 
Recebimento: 23/03/2007

Aprovação: 18/06/2007

\section{Contato:}

Annette Lareau

University of Mariland/Department of Sociology

College Park, MD 20742

301.405.1000/USA

alareau@socy.umd.edu 